\title{
Burle Marx e o Parque Ibirapuera: quatro décadas de descompasso (1953 - 1993)
}

\author{
Burle Marx and Ibirapuera Park: Four Decades Out of Sync (1953-1993)
}

\author{
FERNANDA ARAUJO CURI' \\ Universidade de São Paulo / São Paulo, SP, Brasil
}

RESUMO: Uma das grandes imprecisões que atravessam as seis décadas de história do Parque Ibirapuera é que seu projeto paisagístico teve a autoria de Roberto Burle Marx, o principal nome do paisagismo brasileiro. Este artigo busca reconstruir os processos de aproximação e desaproximação do paisagista com o parque e suas propostas de intervenção nos anos 1950, 1970 e 1990. Visa, ainda, retraçar as razões pelas quais tais projetos encontraram resistência à sua realização, pois apenas o último gerou resultados práticos e, ainda assim, parciais, o que torna o equívoco de atribuição, ainda corrente, um mito que neutraliza um processo histórico bastante tumultuado.

PALAVRAS-CHAVE: Burle Marx. Parque Ibirapuera. São Paulo. Paisagismo brasileiro. Oscar Niemeyer.

ABSTRACT: One of the great misperceptions that has persisted over the six decades of the history of São Paulo's Ibirapuera Park is that it was designed by Roberto Burle Marx, the biggest name in Brazilian landscape design. This article seeks to recover the pattern of approach and distancing of the landscaper with the park and his proposed interventions in the 1950s, 1970s and 1990s. It also aims to show the reasons why these projects met resistance, with only the latter generating practical, if partial, results, making the misunderstanding a myth that obscures a tumultuous historical process.

KEYWORDS: Burle Marx, Ibirapuera Park, São Paulo, brazilian landscaping, Oscar Niemeyer.

\begin{abstract}
1. Arquiteta e museóloga, Mestre em Museologia pela Reinwardt Academie (Amsterdam) e doutoranda na Faculdade de Arquitetura e Urbanismo da Universidade de São Paulo (FAU-USP) onde desenvolve a pesquisa Ibirapuera. Metáfora urbana. São Paulo público E privado (1954-2017), sob orientação do Prof. Dr. Paulo César Garcez Marins. Bolsista de doutorado-sanduíche da Coordenação de Aperfeiçoamento de Pessoal de Nível Superior (Capes), do Ministério da Educação, junto ao Centre de recherches sur le Brésil colonial et contemporain (CRBC) de l'École des Hautes Études em Sciences Sociales (2017). Desde 2011, atua como pesquisadora no Arquivo Histórico Wanda Svevo da Fundação Bienal de São Paulo, localizado no Parque Ibirapuera. A autora agradece a FAU-USP pelo suporte financeiro para a compra dos direitos autorais das imagens utilizadas neste artigo, que de outra forma não seria possível. Email: <fernan dacuri@gmail.com>.
\end{abstract}


2. Gastos com as obras do Ibirapuera, O Estado de $S$. Paulo, 21/8/1954.

3. Ibidem.

4. Ver Ivanir Reis Neves Abreu (2007, p. 9).

\section{INTRODUÇÃO}

Informa a Comissão do IV Centenário que o cimento consumido nas obras do Parque Ibirapuera alcançaria, se fossem empilhados os sacos, uma altura equivalente a seis vezes a do Everest, a maior montanha da Terra. $\bigcirc$ ferro empregado corresponde, aproximadamente, ao peso de 60 locomotivas. A área construída comportaria 2.300 casas, a pavimentada equivale a dez quilômetros de rua, com dez metros de largura, e a ajardinada, ao Parque D. Pedro II. ${ }^{2}$

Com essas inusitadas comparações, o jornal O Estado de S. Paulo, um dos principais do Brasil, comentava "Os gastos com as obras do lbirapuera" na notícia publicada no dia da inauguração do parque, em 21 de agosto de 1954. Certamente, era muito cimento, ferro e área pavimentada, algo que causava estranhamento, pois se tratava, afinal, de um novo parque, cuja área verde equivalia ao mencionado Parque Dom Pedro II, o maior do centro da cidade de São Paulo. Ainda de acordo com os números dados pelo jornal, haviam sido empregados 21 milhões de cruzeiros em obras de arruamento 1100 mil m² de área pavimentada e $200 \mathrm{mil} \mathrm{m}^{2}$ de área para estacionamento de veículos), enquanto foram destinados apenas 5 milhões "aos jardins, que ocupam uma área gramada de $430 \mathrm{mil} \mathrm{m}^{2 \prime}$. $^{3}$

$\bigcirc$ Parque Ibirapuera surgia então com uma peculiaridade: a de ser um parque e, portanto, uma área verde, mas com um imenso conjunto de ruas internas e de edificações de concreto armado.

Esse conjunto arquitetônico, de caráter permanente, foi concebido para abrigar as principais exposiç̃ões comemorativas do aniversário de 400 anos da cidade, uma metrópole emergente que nesse ano de 1954 tornou-se a cidade mais populosa do Brasil. O grande evento, nomeado IV Centenário da Cidade de São Paulo, foi possivelmente a maior festa que já aconteceu nessa cidade, mobilizando os poderes público, privado, eclesiástico, militar, além de centenas de milhares de habitantes. $\bigcirc$ Ibirapuera era, assim, o símbolo do desenvolvimento da metrópole moderna, industrializada e internacional - ou a expressão do desejo da elite industrial paulistana de pontuar os espaços da cidade com evidências monumentais da modernidade. ${ }^{4} \mathrm{~A}$ extensa programação comemorativa no lbirapuera incluía eventos como a $2^{a}$ Bienal do Museu de Arte Moderna de São Paulo, que pré-inaugurou o parque, em dezembro de 1953, ocupando os dois únicos pavilhões já concluídos, a Exposição do IV Centenário, mostra que inaugurou o parque oficialmente, em agosto de 1954, apresentando uma visão conjunta da cultura e do trabalho dos países participantes, e a I Feira Internacional de São Paulo, grande exposição industrial inaugurada em novembro. 
Para abrigar esse conjunto de eventos, a Comissão do IV Centenário encomendou o projeto dos pavilhões a uma equipe chefiada pelo arquiteto brasileiro de maior projeção internacional na época, Oscar Niemeyer, ${ }^{5}$ que concebeu as edificações dentro de sua plástica formal ousada, marcada pelo uso de curvas que contrastavam com os grandes volumes prismáticos inspirados nas propostas arquiteturais de Le Corbusier.

Nesse período, Niemeyer "encontrava-se ocupado na busca de um repertório formal próprio e de novas possibilidades estruturais em concreto armado", " algo que iá ensaiara na década anterior no conjunto da Pampulha, erguido em Belo Horizonte. As edificações previstas para São Paulo, de porte muito maior, permitiam a Niemeyer conceber seu mais ambicioso projeto até então. Ali, além dos enormes pavilhões de concreto que o programa de feiras e exposições do IV Centenário exigia, também seria erguido o elemento arquitetônico de união entre eles, conhecido como a "grande marquise". A extensa cobertura desempenhava o papel ordenador que na Pampulha era realizado pelo lago, o que tornava a marquise uma espécie de "espelho d'água de concreto".?

Em sua pesquisa sobre o Parque Ibirapuera entre 1926 e 1954,8 Ana Claudia Barone problematiza as oposições expressas à época quanto à construção dos grandes pavilhões de Niemeyer no parque, lembrando os argumentos que sugeriam outros locais para a convergência das comemorações do IV Centenário (como o Anhembi, na zona norte, ou o futuro campus da USP no Butantã, zona oeste da cidade), de modo que o parque restasse inteiramente verde, livre de construções (que ocupariam cerca de 5\% do terreno). Uma outra polêmica também existiu, entre os que defendiam as construções: aqueles edifícios deveriam ser provisórios ou permanentes? Durante os anos da construção do lbirapuera, entre 1951 e 1953, o jornal O Estado de S. Paulo foi um dos principais responsáveis por fazer ecoar a defesa do verde, como detectado por Barone. Posteriormente, com os pavilhões de Niemeyer já em construção (nomeados "Palácios", quiçá para reforçar sua permanência), tais disputas desaparecem - e o foco dos conflitos se deslocou para a questão do uso e função dos edifícios. ${ }^{9}$

De modo semelhante a esse período estudado por Barone e que antecedera a inauguração do Ibirapuera, em 1954, as mais de seis décadas que transcorreram desde então revelam uma trajetória marcada por conflitos e disputas, essencialmente relacionados à oposição "verde x concreto". Essa tensão, inerente ao modo como o espaço foi implantado e por vezes compreendida como uma eterna disputa entre adversários, induziu a uma trajetória de parque fragmentado e essencialmente dividido entre "área cultural" e "área natural".
5. Em equipe composta pelos arquitetos Eduardo Kneese de Mello, Zenon Lotufo, Hélio Uchôa Cavalcanti e colaboração de Gauss Estelita e Carlos Lemos.

6. Ver Simone Neiva Loures Gonçalves (2010).

7. Ver Paulo César Garcez Marins (1998-1999, p. 26).

8. Ver Ana Cláudia Castilho Barone (2007e 2009).

9. Barone (2007) também identificou inúmeros conflitos já existentes desde finais da década de 1920 , após a determinação do prefeito Pires do Rio (1926) de que naquele território fosse construído um parque: conflitos jurídicos que envolviam, além da invasão de intrusos, documentos falsificados e uma enorme confusão a respeito das propriedades de terra. Muitas dessas confusões permanecem sem solução até os dias de hoje. 
10. Alguns exemplos dessa atribuição errônea em matérias de jornal nas últimas décadas podem ser verificados em: Rowan Moore (2015), Maria Inês de Camargo (1994), Adriana Moreira (1997), o Parque que virou símbolo de São Paulo (1987) e Leila Chacon (1981).

11. Prefeitura... (2005). Até junho de 2016, quando foi acessado pela última vez, havia no site da Prefeitura de São Paulo, na página sobre o Ibirapuera, a informação de que "Oscar Niemeyer foi responsável pelo projeto arquitetônico, e Roberto Burle Marx pela constituição paisagística" do parque, datada de 7 de novembro 2005. Entre a escrita e a publicação desse artigo, o site da Prefeitura foi refeito e essa página foi retirada, mas ainda é possível recuperá-la em: <ht tps://web.archive.org/ web/20160303204749/ht tp://www.prefeitura.sp. gov.br/portal/a_cidade/his toria/fatos_historicos/in dex.php?p=5604> (consultado $25 / 10 / 2005$ )
Com maior ênfase dada ao projeto arquitetônico do lbirapuera, menos importância foi atribuída ao seu projeto paisagístico, o que gerou uma série de imprecisões a esse respeito. Assim, há décadas é comum estar expresso nos mais diversos veículos de comunicação, ${ }^{10}$ passando pelo próprio site da Prefeitura de São Paulo, ${ }^{11}$ que o projeto paisagístico do parque teve a autoria de Roberto Burle Marx.

De fato, um projeto paisagístico inicial para o Ibirapuera foi desenvolvido em 1953 por Burle Marx, profissional que já trabalhara com Oscar Niemeyer em projetos anteriores e que, como ele, gozava de prestígio nacional e internacional. Juntos, iá haviam colaborado em projetos públicos, como o do Ministério da Educação e Saúde (MES) - atual Palácio Capanema, no Rio de Janeiro (1938) - e o já mencionado conjunto da Pampulha, em Belo Horizonte (1942). Também atuaram em conjunto para a realização de projetos privados, como o Grande Hotel de Ouro Preto (1942), ou em diversas residências, como a de Francisco Inácio Peixoło em Cataguases (1942), a de Juscelino Kubitschek em Belo Horizonte (1943), ou a de Burton Tremaine, em Santa Barbara, Califórnia (1948). Os projetos de Burle Marx nesse período, marcados pelo uso intenso de flora tropical e cromatismos contrastantes, fundaram o paisagismo moderno no Brasil. Ele era, assim, um nome à altura de Oscar Niemeyer aos olhos das autoridades paulistas, que desejavam que o Parque Ibirapuera alcançasse grande visibilidade e repercussão. Entretanto, esse projeto de Burle Marx não foi implantado.

Este artigo visa, portanto, estabelecer uma análise da relação de Burle Marx com o Parque lbirapuera, redesenhando os processos de aproximação e afastamento do paisagista com o parque e suas propostas de intervenção, que ocorreram nos anos 1950, 1970 e 1990. Além de ampliar o debate já estabelecido sobre o projeto de 1953, deter-me-ei nos outros dois projetos que Burle Marx propôs para o parque e que ainda não receberam um olhar mais atento. Partindo dos estudos anteriores que apontam as oposições que inviabilizaram seu primeiro projeto, meu objetivo é compreender as razões pelas quais tais propostas encontraram resistência à sua realização, uma vez que nenhuma delas foi implementada integralmente. Busco, sobretudo, investigar as diferentes forças que impediram que Burle Marx, o maior paisagista brasileiro do século XX, pudesse lograr sua inscrição efetiva no principal parque da cidade de São Paulo. Um parque que, ao longo do tempo, foi sendo administrado sem planejamento, sem nunca ter realmente tido um projeto paisagístico à altura de sua importância e de seu impacto social e urbanístico. Como se verá, a reação final de Burle Marx a essa situação foi de cunho patrimonial, no sentido de monumentalizar seu projeto jamais realizado. 
Cabe interrogar, ainda, em que medida essas quatro décadas de descompasso na história do Parque Ibirapuera (1953-1993) espelham uma discórdia central para a compreensão do projeto moderno paulistano, revelando, sobretudo, a impossibilidade de que tal projeto se concretize sobre as bases de um ideal de desenvolvimento em que o "concreto" prima sobre o "verde".

\section{ANOS 1950: BRIGA DE EGOS, ALTO CUSTO OU MOMENTO INOPORTUNO?}

$\bigcirc$ primeiro projeto paisagístico de Burle Marx para o Ibirapuera foi preterido, durante o processo de construção do parque, em favor do plano do arquiteto, paisagista e engenheiro agrônomo Otávio Augusto Teixeira Mendes. ${ }^{12}$ Para tal fato, há três possíveis hipóteses que serão analisadas aqui: a de que haveria uma obstrução ao projeto de Burle Marx por Oscar Niemeyer, a de que o alto custo de seu projeto tenha sido um fator inviabilizador e a de que, simplesmente, seu projeto chegou em um momento não muito oportuno.

A hipótese de que disputas político-pessoais entre Burle Marx e Oscar Niemeyer sempre estiveram em jogo - personificando a disputa "verde x concreto" - é alvo de especulação em diversas pesquisas. Fabiano Lemes de Oliveira realizou um estudo dos projetos para o Ibirapuera anteriores ao de Niemeyer, como o de Reynaldo Dierberger (1930) e o de Cristiano Stockler das Neves (1951), buscando compreender as diferentes propostas de parques modernos por eles desenvolvidas. Oliveira atém-se no lbirapuera como arena das "diversas modernidades pretendidas", 13 chamando a atenção para a implantação do parque como lugar "essencialmente verde, pautado em gramados e áreas arborizadas, tal como defendido por Le Corbusier e possivelmente acorde com as preferências de Oscar Niemeyer". ${ }^{14}$

Já Cássia Mariano, em seu estudo sobre Otávio Augusto Teixeira Mendes, defende que foi exatamente o tratamento que ele definiu para o lbirapuera o que tornou aquele logradouro, de fato, um parque. Como já havia também destacado Oliveira, "Otávio Augusto Teixeira Mendes também se vinculava à produção modernista e encampava princípios semelhantes aos preconizados por Burle Marx, quais sejam a utilização de flora autóctone, o combate à estilização europeia dos jardins no Brasil, a forte preocupação preservacionista e uma ritmação ímpar do desenho". ${ }^{15}$

Mariano ainda observa que a má conservação do parque e o fato de que o projeto de Teixeira Mendes foi apenas parcialmente implantado, somados à
12. Segundo Cássia Mariano (2005, p. 48, 49 e 53), Otávio Augusto Teixeira Mendes (1907-1988), além de um grande pianista, "foi um profissional inovador. Depurou ensinamentos da escola de agronomia de Piracicaba (1939) [onde "sua família possuía tradição de pesquisa, ensino e trabalho"] com a pós-graduação em arquitetura, planejamento e preservação na Universidade de Columbia, EUA (1950)", de onde, "ao retornar, passou a se auto intitular arquiteto paisagista". Teixeira Mendes integrou o Serviço Florestal do Estado de São Paulo entre 1942 e 1968. Além do Parque Ibirapuera, atuou em projetos importantes na área ambiental, como a criação do Parque Turístico da Cantareira e o parque da Fundação Maria Luísa e Oscar Americano.

13. Cf. Fabiano Lemes Oliveira (2002, p.1).

14. Cf. Fabiano Lemes Oliveira (2008, p.24).

15. Cf. Fabiano Lemes Oliveira (2003b, p.14). 
16. Cf. Cássia Mariano (2005, p.111).

17. Cf. Claude Vincent (1953, p. 55).

atribuição da autoria a Burle Marx, fizeram com que a verdadeira autoria do projeto efetivamente implantado fosse "sendo eclipsada", na "indireta proporção em que o parque passou a ser reconhecido como referencial na metrópole paulista"16 - o que ainda foi reforçado pelo fato de que fora o projeto de Burle Marx que tivera ampla divulgação na imprensa à época da construção do parque.

A revista Brasil Arquitetura Contemporânea (BAC), por exemplo, na sua edição de janeiro de 1954, apresentou uma matéria de Joaquim Cardoso sobre - "Conjunto Arquitetônico de lbirapuera" que trazia um encarte com o projeto de Burle Marx em preto e branco (Figura 1) e texto de Claude Vincent denominado "Jardins do Parque Ibirapuera - Roberto Burle Marx". Vincent sintetizava:

A grande preocupação do paisagista foi a de criar jardins geométricos, mas ao mesmo tempo assimétricos, utilizando-se de elementos construtivos policromos, em relação com plantas ricas em cores e texturas, muitas vezes autóctones, elementos esses que seriam valorizados pelo uso da água, não só como elemento vivificador e como espelho mas também como escultura líquida, e modificadora de cores quando utilizada em tanques revestidos de mosaico colorido. ${ }^{17}$

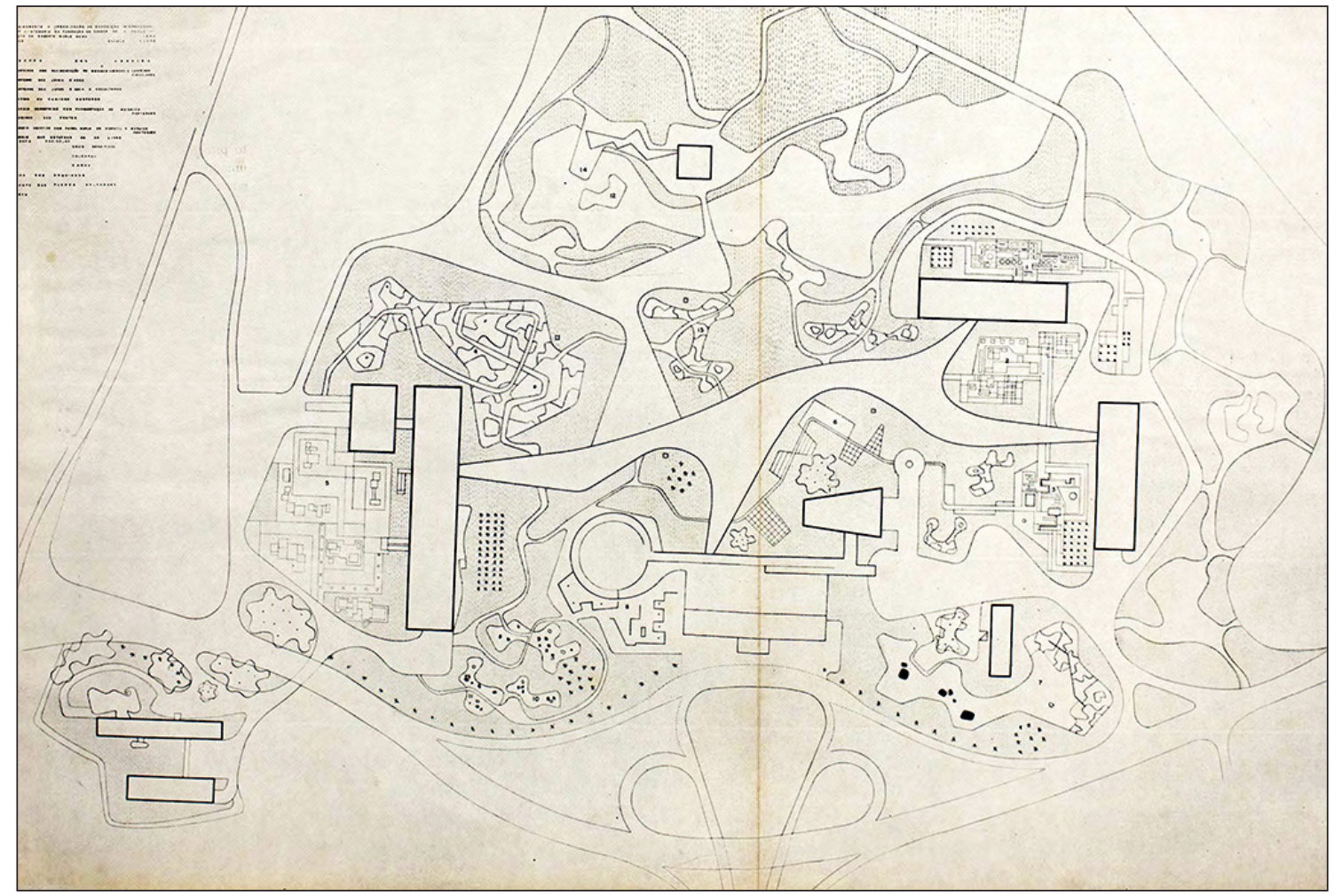

Figura 1 - Projeto paisagístico de Burle Marx para o Parque Ibirapuera, 1953. Fonte: Claude Vincent (1954, 5758). (C) Escritório de Paisagismo Burle Marx. 
Esse projeto, que evitava o uso exclusivo das linhas curvas que priorizara até aquele ponto de sua carreira, era muito impactante. Três de suas pranchas originais (Figuras 2, 3 e 4) - apresentando planta geral, detalhe e perspectiva, pintadas com guache ${ }^{18}$ - permitem constatar sua ideia de preencher com cores e texturas as áreas externas das grandes edificações (formas em cinza), criando imensos jardins-pontes entre o ambiente construído e os gramados e bosques, que deveriam compor a maior parte da área verde.

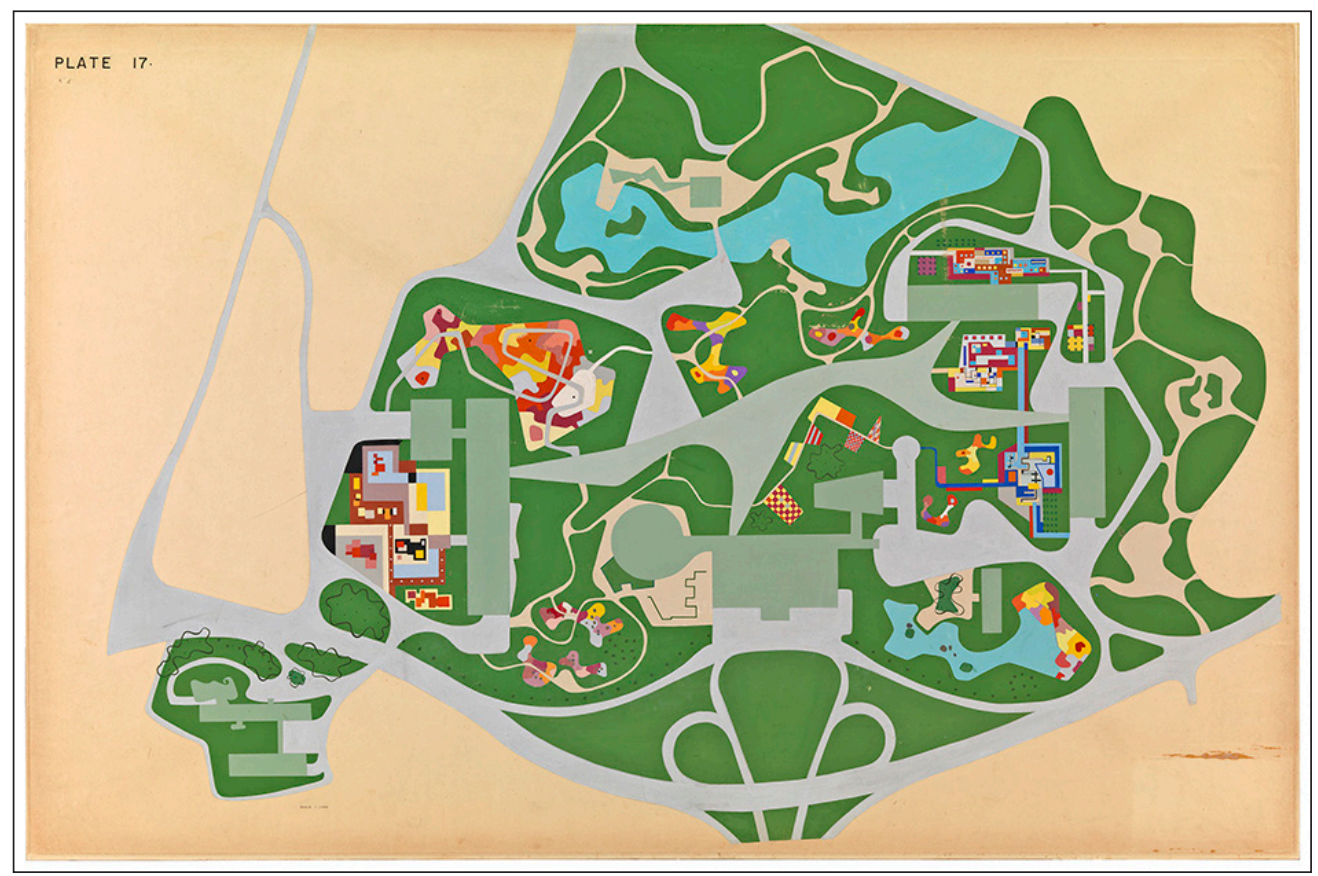

Figura 2 - Roberto Burle Marx (1909-1994). Projeto para o Parque Ibirapuera, São Paulo, Brasil, 1953. Gouache and graphite on board. $391 / 2 \times 591 / 2(100.3 \times 151.1 \mathrm{~cm})$. Acervo do Museum of Modern Art (MoMA) Nova York (Gift of Roblee McCarthy Jr. Fund and Lily Auchincloss Fund. Acc. num. 157.19911. () 2017. Digital image, The Museum of Modern Art, New York/Scala, Florence. (C) Escritório de Paisagismo Burle Marx.

O texto de Claude Vincent na BAC trazia ricos detalhes sobre cada um dos 14 parterres (Figura 1), em que dissertava sobre suas cores, texturas, formas, ritmos, matizes, folhas, folhagens, elevações, justaposições, sobreposições, mosaicos. ${ }^{19}$ $\bigcirc$ "Detalhe n 5" (Figura 3), por exemplo, pode ser mais bem compreendido em perspectiva (Figura 4): um grande jardim contíguo ao atual Pavilhão da Bienal, onde hoje se encontra um estacionamento. A minuciosa descrição de Vincent enfatiza o nível de sofisticação do jardim que Burle Marx propunha para o entorno daquele enorme edifício:
18. As pranchas pertencem ao acervo do Museu de Arte Moderna de Nova York (MoMA).

19. Embora as ilustrações do artigo de Claude Vincent tenham sido publicadas em preto e branco, é muito provável que ele tenha tido acesso aos projetos originais em guache - parte deles hoje pertencente ao Museum of Modern Art de Nova York -, dado que comenta com precisão aspectos cromáticos presentes nesses originais. 
20. Cf. Claude Vincent (1954, p.57 e 58).

21. Cf. Fabiano Lemes Oliveira (2003b, p. 13).
Em (5) o contraste entre as plantas e o elemento construtivo estabelece-se por meio do uso do piso de "pedra portuguesa", em superfícies de basalto preto e de arenito leitoso e côr de tijolo, em padrões inspirados em tapeçarias baianas. Os tanques seguem formas geométricas, assimétricas, sendo, também, revestidos de mosaico vitroso azul. Canteiros de flores, em forma de paralelepípedos, erguem-se nestes lagos, colocados estritamente em grupos alternados e opostos, o primeiro grupo em tons que vão do roxo até o lilás, o segundo numa sequência de vermelhos; e no terceiro grupo, a côr predominante será o amarelo em vários matizes, com contrastes de cinzento e azul claro. Estes amarelos conduzem ao eixo do jardim, onde serão reunidas as três côres básicas, o roxo, o vermelho e o amarelo. ${ }^{20}$

Figura 3 - Roberto Burle Marx. Projeto de jardim para o Parque Ibirapuera, 1953. Acervo do Museum of Moderna Art (MoMA), Nova York. <https://www.moma.org/collection/works/286>

Figura 4 - Roberto Burle Marx. Projeto de jardim em perspectiva para o Parque lbirapuera, 1953. Acervo do Museum of Moderna Art (MoMA), Nova York. <hitps://www.moma.org/collection/works/253>

Entre os pesquisadores que já trataram do tema, percebe-se um estranhamento comum ao fato de que esse projeto de Burle Marx, que sintetizava jardins e parque, acabou por não ser executado, o que gerou especulações diversas. Fabiano de Oliveira sinaliza que teria havido um veto de Niemeyer, receoso da competição que os jardins estabeleceriam com seus edifícios:

O projeto de Burle Marx era assaz vibrante. A composição reverberava cores e situações ao longo de todo o conjunto construído. Há a hipótese de que Niemeyer tenha procurado evitar tal solução paisagística em função da preferência por uma concepção mais homogênea, que procurasse enfocar os edifícios, proporcionando perspectivas e que, de nenhuma forma, competisse visualmente com o proposto por sua equipe. Assim, pode ter havido uma interferência direta de Oscar a fim de se optar por uma proposta cujas características se aproximassem do que imaginava o ideal para a situação. ${ }^{21}$

A proposta de Burle Marx trazia, de fato, elementos com potencial para desviar o foco do conjunto de edifícios de Niemeyer, propondo, inclusive, algumas intervenções em seu entorno. Do lado oposto do edifício da Bienal, por exemplo (Figura 5), por onde sai a grande marquise, a proposta do paisagista nada tinha de modesta, sugerindo, inclusive, uma plataforma elevada, assim descrita por Flavio Motta:

Nesse jardim foram pensados caminhos suspensos para se ver as plantas de cima para baixo, e ao mesmo tempo, numa trajetória em espiral, conhecer perspectivas constantemente renovadas. Haveria também o caminho dos jatos d'água, que, através de um dispositivo especial, ficariam entre as flores e variavam de intensidade, conforme as nuanças de vege- 
tação. Também foram projetados grupos ecológicos, murais, esculturas e pequenos volumes florais para intensificar o valor cromático dos canteiros. ${ }^{22}$

Tal jardim também foi minuciosamente descrito por Claude Vincent na revista $B A C$ :

O Caminho Elevado (4) terá um vão de concreto armado, em forma de montanha russa, subindo e descendo, mas sempre acima do nível do parterre de folhagens e flores de cores vivas, de texturas e alturas diferentes, plantadas em forma de "puzzle", ou seja, de uma "pintura" abstrata em formas livres. Dentro dêste parterre serão colocados elementos escultóricos baseados nas formas do cilindro e do paralelepípedo. $\bigcirc$ visitante poderá realizar uma série de experiências artísticas ao contemplar o jardim, primeiro no nível normal, depois, subindo, contemplando as diferentes facetas das esculturas, e, finalmente, do ponto de vista de uma plataforma, onde serão colocados bancos, examinando o todo, de cima para baixo. Depois da plataforma, o caminho sobe, para, finalmente, descer até a saída. Neste jardim, em violento contraste com o "puzzle" colorido e com as áreas plantadas de grama, haverá uma secção recoberta de areia alva, com bancos de granito e "boulders". 23

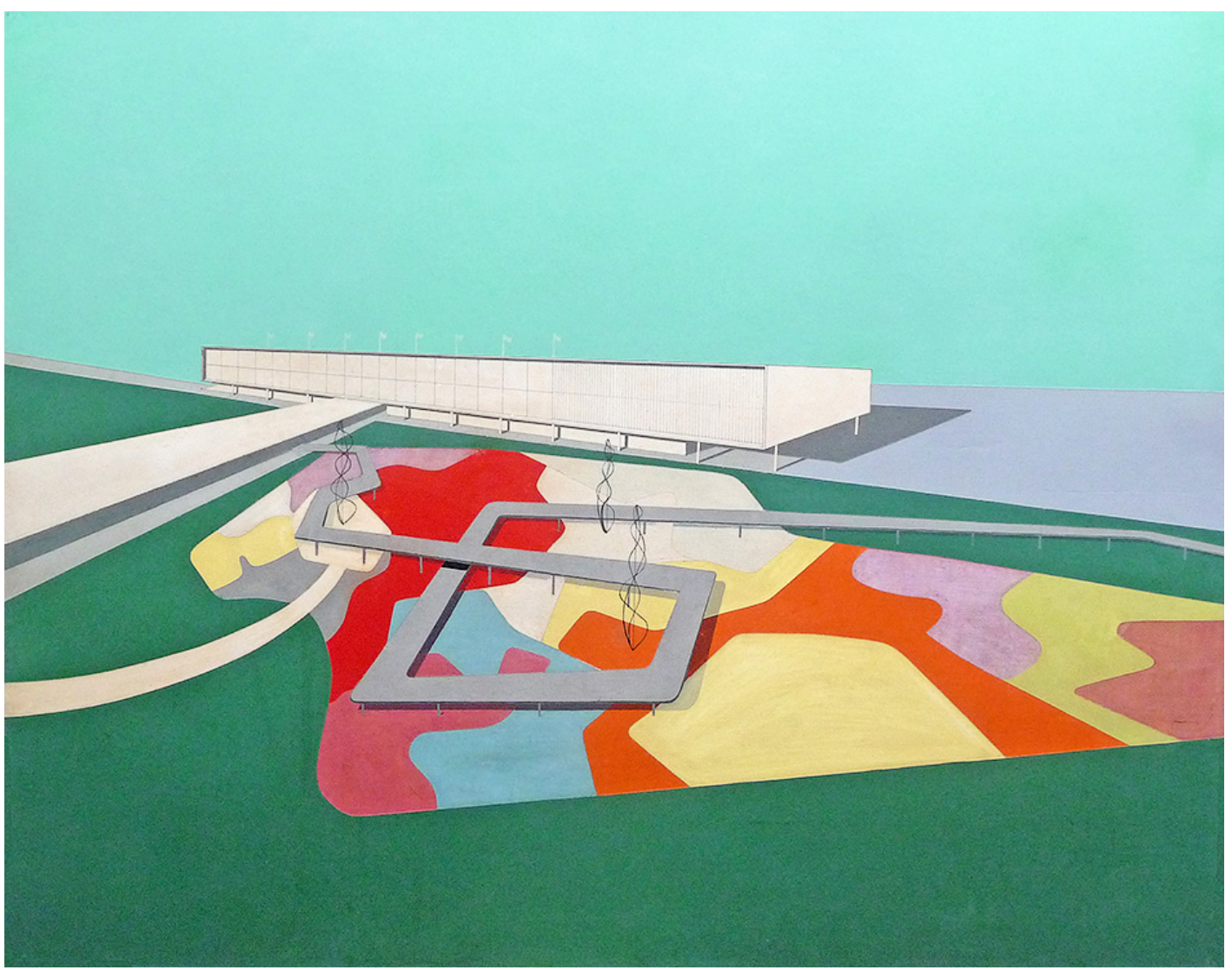

Figura 5 - Roberto Burle Marx. Projeto em perspectiva de jardim para o Parque Ibirapuera, 1953. @ Escritório de Paisagismo Burle Marx.
22. Cf. Moderno MAM extra. Roberto Burle Marx, 100 anos... (2009, p. 9).

23. Cf. Claude Vincent (1954, p. 56 e 57). 
24. Cf. Zenon Lotufo (1953).

25. Cf. Silvio Luiz Lofego (2004, p. 85 e 86$)$.

26. Cf. Manuella Marianna Andrade (2004).
A hipótese de que o projeto paisagístico de Burle Marx chegara em um momento inoportuno e a de que seu alto custo o teria inviabilizado estão relacionadas e se entrecruzam. A escassa documentação existente indica que, de fato, tratava-se de um momento complicado para a sua aprovação. Em carta ao presidente da Comissão do IV Centenário, Francisco [Ciccillo] Matarazzo Sobrinho, datada de 27 de março de 1953, Zenon Lotufo, em nome da equipe de arquitetos liderada por Niemeyer, encaminhava o "ante-projéto de ajardinamento da área Exposição do Parque Ibirapuéra, elaborado pelo sr. Roberto Burle Marx". ${ }^{24}$ A carta de Lotufo, contudo, chegou poucos dias antes de uma importante mudança no cenário político paulistano: o prefeito Jânio Quadros, recentemente eleito, tomou posse, no dia 8 de abril, em meio aos atrasos e à construção acelerada do Ibirapuera, tendo em vista a aproximação do início da programação dos festejos, o que provocou um abalo na "aparente harmonia" entre a prefeitura e a Comissão do IV Centenário, como relatou Silvio Lofego:

Essa mudança provoca de imediato alguns incômodos junto àqueles que estavam à frente das obras (...) com a suspensão de licitações já programadas, provocando ainda mais atrasos. (...) Jânio Quadros demonstrava má vontade em relação à execução das obras que envolviam o Parque Ibirapuera (...) o jogo político e os interesses partidários prevaleceram. ${ }^{25}$

De fato, aquele foi um período de relações turbulentas. Um ano após a posse de Jânio Quadros, as desavenças entre ele e o presidente da comissão, Ciccillo Matarazzo, culminaram na demissão deste, poucos meses antes da inauguração do parque. Pode-se pensar, portanto, que realmente não fora oportuna a chegada de um novo projeto de ajardinamento para o Ibirapuera naquele momento de transição da gestão municipal. Não seria nada estratégico começar um novo projeto, dado o curto prazo disponível até a inauguração, até então prevista para 25 de janeiro de 1954, dia do aniversário da cidade - a inauguração acabou atrasando sete meses. Possivelmente, dar continuidade ao que já estava em andamento seria mesmo o mais propício, e já havia um projeto paisagístico para o parque antes da entrega daquele realizado por Burle Marx.

Desde meados de 1952, Otavio Augusto Teixeira Mendes, funcionário público estadual que integrava a equipe técnica da Comissão do IV Centenário sob a supervisão do engenheiro Ernesto de Faria Alves, já havia iniciado estudos para o projeto paisagístico do parque. Manuella de Andrade localizou no Arquivo Histórico de São Paulo um parecer de Teixeira Mendes, datado de 25 de abril de 1953, emitido no mês seguinte à carta de Lotufo que encaminhara à Comissão do IV Centenário o projeto de Burle Marx. ${ }^{26}$ Nesse parecer, ele 
enumera uma série de considerações contrárias a esse projeto, apresentando também suas próprias propostas, já em estudo. Seus argumentos começavam por fazer uma distinção clara: um parque não deveria ser um "conjunto de jardins", "de construção caríssima" e conservação "mais onerosa ainda", como, a seu ver, eram características do projeto proposto por Burle Marx. Por certo, o valor da construção e da manutenção dos sofisticados jardins de Marx era algo a ser colocado em pauta, mas o fator determinante assinalado por Mendes para que se vetasse a proposta de Burle Marx era o fato de que ele havia projetado a partir de um "terreno ideal", supostamente plano, o que, de fato, não correspondia à realidade.

Nesse parecer, Teixeira Mendes ainda declarava que já havia iniciado o seu projeto paisagístico para o lbirapuera, incluindo levantamentos da superfície do terreno, da vegetação existente, o projeto do lago e as ruas internas do parque - o que, no projeto de Marx, não estava contemplado. Referindo-se principalmente ao jardim elevado (Figura 5), afirmava que este "traria grande movimento de terra". $\bigcirc$ argumento final era que o projeto de Burle Marx oneraria "sobremodo aquilo que já está em andamento", representando "perda não só de material como também de mais de um ano de estudos e trabalhos" realizados pela "equipe de técnicos especializados", "à disposição da Comissão do IV Centenário". Concluía reforçando uma das objeções principais: "E, é bom que insistamos nisto, não há mais tempo a se perder, porisso [sic] que a data das comemorações se aproxima rapidamente" ${ }^{27}$ Como havia imediatismo e os recursos tornavam-se cada vez mais escassos à medida que os grandes pavilhões iam sendo construídos a toque de caixa, além de toda a infraestrutura e produção que o ano comemorativo demandava, a opção por um projeto sem ônus suplementar, realizado por um "técnico especializado" do Estado "à disposição da Comissão", é plausível.

É indispensável notar que, nos projetos finais de 1953, realizados tanto por Niemeyer quanto por Teixeira Mendes (Figura 7), o traçado do lago já era coincidente entre ambos, enquanto a proposta de Burle Marx, também de 1953, deles diferia, indicando não ter havido sinergia entre Niemeyer e seu antigo parceiro. Como constava no parecer de Teixeira Mendes, Burle Marx não havia levado em conta "o conjunto de perspectivas" dos edifícios. Além da diferença no desenho do lago, nota-se também que o projeto de Burle Marx ainda trazia o restaurante, com a sua pequena marquise serpentinada, na parte superior do lago (Figura 6), enquanto, nos projetos de Teixeira Mendes e de Niemeyer, o restaurante já havia sido suprimido (Figura 7).

A questão do lago pode ser mais bem compreendida graças à análise de relatórios e de correspondência datadas entre dezembro de 1952 e janeiro de 
28. Cf. Ernesto de Faria Alves 1953).

29. Ver Relatório (1952).
1953, na qual a equipe técnica da Comissão do IV Centenário argumentava que o traçado do lago proposto inicialmente pela equipe de Niemeyer custaria três vezes mais do que o proposto pela equipe técnica. Isso acarretou uma mudança de traçado, chegando-se a "um meio termo satisfatório" 28 entre ambos os projetos, aprovado por Zenon Lotufo no mês seguinte. Pelo visto, essa mudança não foi comunicada a Burle Marx, que entregou seu projeto ao próprio Lotufo, dois meses após a modificação aprovada, ainda com o traçado antigo do lago. ${ }^{29}$
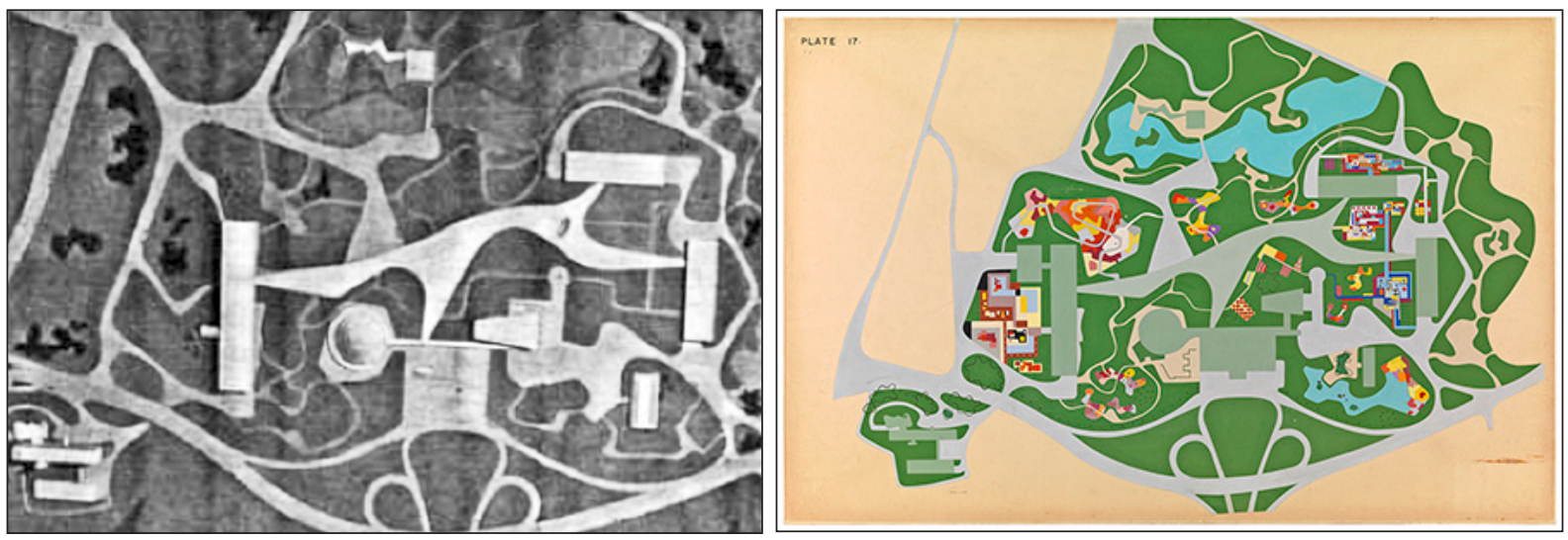

Figura 6 - À esquerda, maquete do projeto aprovado realizado pela equipe liderada por Oscar Niemeyer para o Parque Ibirapuera. 1953. Fonte: (Niemeyer, 1955, p. 21). À direita, projeto paisagístico de Roberto Burle Marxpara o Parque Ibirapuera, 1953) MoMA Collection, Nova York. (c) Escritório de Paisagismo Burle Marx.
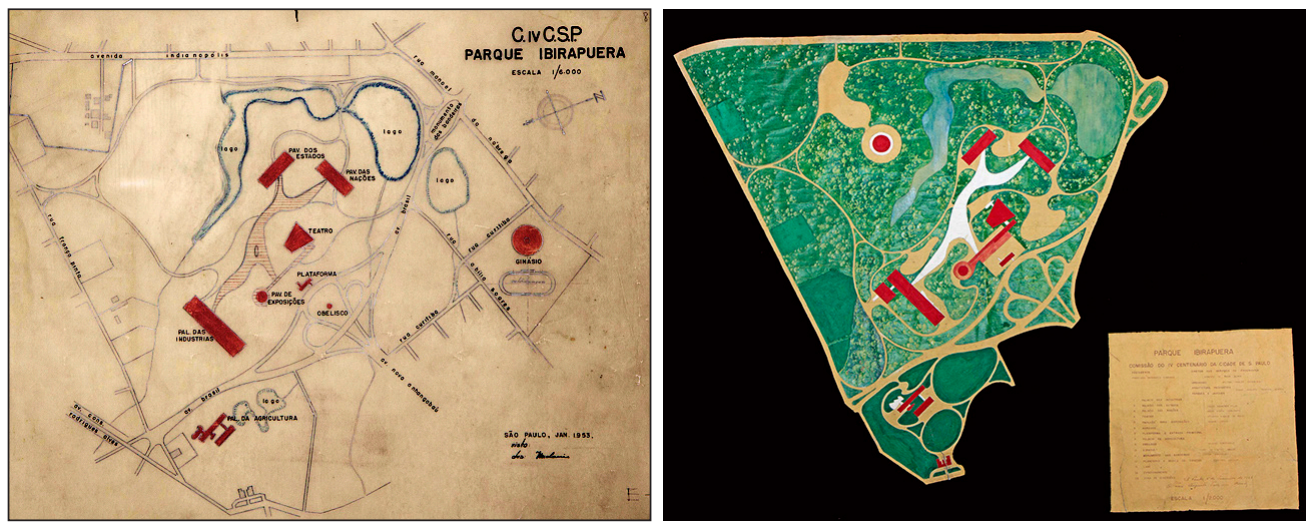

Figura 7 - À esquerda, projeto final da equipe de Niemeyer para o Parque Ibirapuera, 1953. Fonte: Arquivo Histórico de São Paulo À direita, projeto paisagístico de Otavio Augusto Teixeira Mendes para o Parque Ibirapuera, 1953. Fonte: Arquivo Histórico de São Paulo., São Paulo.

$\bigcirc$ argumento de que o custo elevado teria sido um fator que justificaria a recusa do projeto de Burle Marx não encontra eco na documentação consultada, reforçando mais uma vez a hipótese de que Niemeyer possa ter agido nos 
bastidores contra sua escolha, somada ao momento inoportuno em que a proposta foi entregue. De fato, na carta de Zenon Lotufo estava detalhado o orçamento da proposta de Burle Marx, com custo total de 20 milhões de cruzeiros, salientando que esse valor poderia diminuir, pois "a própria prefeitura poderá fornecer 95\% das plantas vivas, adubo animal e mão de obra para o plantio". ${ }^{30}$ Esses itens já consumiriam mais da metade do orçamento (14,8 milhões), o que leva a pensar que, caso se efetivasse tal colaboração com a prefeitura - o que seria provável, pois, como afirmou Teixeira Mendes no parecer, a "municipalidade possue [sic] viveiros de mudas e outros elementos para a execução do parque" -, o projeto de Burle Marx custaria os mesmos 5 milhões que custaram os jardins de Teixeira Mendes, para a mesma "área ajardinada" de $400 \mathrm{mil} \mathrm{m}^{2}$. E, levando-se em conta a sofisticação e a variedade das espécies escolhidas por Burle Marx, o custobenefício seria outro...

Nesse sentido, como observa Silvio Macedo, o projeto de Teixeira Mendes "é bastante conservador, mas despojado de cenarizações e elementos pitorescos, sendo quase um híbrido formal entre a visão bucólica do passado e a simplicidade modernista". ${ }^{31}$ A aposta na não interferência de ajardinamentos nos edifícios do conjunto arquitetônico, deixando-os soltos em esplanadas, levou a uma proposta simplificada de parque-bosque e áreas gramadas, que ressaltavam os edifícios de Niemeyer na paisagem.

Enfim, como analisado por Cássia Mariano, a proposta de Burle Marx, "que focalizava o entorno do conjunto arquitetônico como jardins temáticos modernos", e a de Teixeira Mendes, "que vislumbrava a totalidade do parque prioritária ao tratamento do entorno das edificações", (...) "não guardam a menor similaridade, nem em conteúdo, nem em conceitos ou em escala", 32 sendo a única semelhança possível de ser apontada a priorização da vegetação nativa em ambos os projetos.

Ainda que a autora também afirme que "princípios modernos foram seguidos por Teixeira Mendes" e que em seus projetos "há reciprocidade com a atuação de Roberto Burle Marx e com a escola norte-americana de desenho de paisagem", 33 é difícil não perceber que as duas propostas são radicalmente diferentes. Basta notar a legenda que consta na única prancha localizada do projeto de Teixeira Mendes, ${ }^{34}$ que referencia apenas o conjunto arquitetônico 11 - Palácio das Indústrias, 2 - Palácio dos Estados...), não informando nada sobre a vegetação utilizada. Além disso, se pensarmos nos dois projetos quanto ao entorno dos edifícios de Niemeyer, o simples fato de uma eventual concentração paisagística nesse aspecto em ambos os projetos não é suficiente para aproximar suas concepções. Podemos pensar que o othar de Burle Marx sobre o parque valorizou
30. Cf. Zenon Lotufo (1953).

31. Cf. Silvio Soares Macedo (2003, p 4).

32. Cf. Cássia Mariano (2005, p.113).

33. Cf. Cássia Mariano (2005, p.48).

34. Ainda de acordo com Cássia Mariano: "Há referência de que para o Ibirapuera ele elaborou entre oitenta e cento e cinquenta desenhos em perspectivas, cortes longitudinais mestres e transversais secundários para estudar o parque, procurando preservar a vegetação existente tanto quanto possível. A imprecisão da quantidade está somada ao infortúnio deles ainda estarem desaparecidos. Salvaram-se apenas dois, cópia da planta do anteprojeto e seu original providencialmente depositados no Arquivo Histórico Washington Luís" [hoje chamado Arquivo Histórico de São Paulo]. Cf. Cássia Mariano (2005, p. 116). 
35. Cf. Cássia Mariano (2005, p.113).

36. Ibidem.

37. Ver "Patrimônio que se desfaz..... (1959), Ferreira Barros (1959); Ibirapuera cai aos pedaços (1959), e O triste exemplo do Ibirapuera (1959).

38. Cf. Jacques Leenhardt (1994, p.26). os entornos das construções no sentido de criar um diálogo com Oscar Niemeyer e entre espaços construídos e vegetação. Mas isso não indica, absolutamente, que o paisagista não tenha tido uma visão global do parque. A escolha por privilegiar o entorno das edificações, contudo, pode estar na origem dos conflitos com o arquiteto.

As diferenças explícitas entre os dois projetos paisagísticos não evitaram, entretanto, o surgimento, a difusão e a manutenção, por muito tempo, de uma confusão sobre a autoria do projeto, que, como vimos, foi ao longo do tempo recorrentemente atribuída a Burle Marx. Segundo Mariano, trata-se de uma "desinformação, conveniente, divulgada pelos órgãos oficiais desde a década de 1970". ${ }^{35}$ Mariano acrescenta ainda que os desentendimentos entre Niemeyer e Burle Marx "desencadeados pelo Ibirapuera minaram e limitaram trabalhos conjuntos posteriores". 36 É necessário lembrar, no entanto, que ambos continuaram atuando em diversos projetos conjuntos - por exemplo, os diferentes edifícios públicos de Brasília erguidos nas décadas de 1950 a 1970, como os ministérios das Relações Exteriores (Itamaraty), da Justiça e do Exército, o Palácio do Jaburu e - Teatro Nacional, ou ainda a nova sede da Manchete no Rio de Janeiro.

Mas, se os desacertos no projeto paisagístico do lbirapuera não minariam a relação entre arquiteto e paisagista, o mesmo não podemos dizer do próprio parque. Menos de cinco anos após os festejos, o lbirapuera já estava "minado", com suas edificações apresentando sinais de ruína e suas áreas verdes, muitos mais modestas do que as projetadas por Burle Marx, em total estado de abandono. As notícias dos jornais da época ${ }^{37}$ não escondiam a frustração com o recém-inaugurado símbolo da cidade, trazendo imagens dos pavilhões modernos já como ruínas de um passado recente.

Podemos conjecturar que, se o projeto paisagístico de Burle Marx tivesse sido implementado, o lbirapuera não teria sido apenas um recinto de exposições, com seus diversos pavilhões abandonados pouco após as comemorações do IV Centenário, e sim um grande conjunto de jardins, que demandaria uma conservação permanente para que ele permanecesse fruível em acordo com o projeto, visto que, como afirma Jacques Leenhardt, "o jardim necessita de cuidados ao longo do tempo e exige do artista tanto previsão como acompanhamento, pelo menos quando possível". ${ }^{38}$ Rosa Kliass, em seu estudo sobre os parques urbanos de São Paulo, é consoante a essa interpretação, pois "o tratamento subsidiário" dados aos jardins no Ibirapuera em relação às edificações "comprometeu o caráter e a escala dos seus espaços". Sem uma "intenção paisagística" claramente expressa na implantação do parque, decorreram inúmeras intervenções que, em sua maioria, prejudicaram as 
condições da área. Como exemplo disso, a arquiteta cita a "fúria arborizadora", que acabou "por destruir ou caracterizar os espaços pela distribuição indiscriminada de árvores" 39 - algo que permanece ocorrendo até hoje.

Uma evidência de que o projeto paisagístico implantado em 1953 foi de fato algo tímido, ou subsidiário, é que, já em maio de 1955, a Sociedade Amigos da Flora Brasílica propunha a criação de um "jardim instrutivo de plantas úteis" no parque. Tal proposta, analisada em reunião da comissão executiva do parque, trouxe à lembrança dos presentes "a existência de um plano anterior, de autoria de Burle Marx". ${ }^{40}$ A comissão chegou, inclusive, a estabelecer contato com o paisagista no Rio de Janeiro, que, lembrando-se dos gastos que teve para elaborar o projeto não implantado, alegou que discordava da ideia de um "jardim instrutivo" e continuava a defender a ideia de algo maior "para um local de exposições culturais e industriais da proporção do lbirapuera". ${ }^{41}$

É preciso frisar que o fracasso de Burle Marx em ver seu projeto de 1953 implementado em São Paulo não impediu seu imenso triunfo no Rio de Janeiro, ao final dessa mesma década. Em 1960, foi inaugurado o parque do Aterro do Flamengo, concebido pelo paisagista e totalmente executado, o que the garantiu uma imensa visibilidade no Brasil. Antes disso, ainda na mesma década de 1950 da construção do Ibirapuera, ele concebera o igualmente gigantesco Parque del Este em Caracas, inaugurado em 1961, o que the garantiu o início de uma consagração internacional. Tais vitórias certamente colocaram a cidade de São Paulo numa situação de desvantagem ao não ter executado o projeto de Burle Marx para o lbirapuera, pelo que a mencionada "desinformação conveniente" pode ser uma espécie de compensação, construída coletivamente, para acertar um erro administrativo. Tal descompasso não seria, contudo, estancado naquele desacerto da década de 1950. Burle Marx foi convocado mais duas vezes para interferir no Ibirapuera e, também nessas ocasiões, suas pretensões foram frustradas.

\section{ANOS 1970: NOVO CONVITE, NOVA FRUSTRAÇÃO}

No começo da década de 1960, o Parque Ibirapuera já era chamado de "Brasilia paulistana", ${ }^{42}$ pois havia se transformado numa espécie de cidade administrativa, com órgãos municipais e estaduais em vários de seus espaços construídos. ${ }^{43} \mathrm{Em}$ 1965, o prefeito Faria Lima chegou a anunciar que iria retomar "o plano de ajardinamento paisagístico de autoria do arquiteto Burle Marx, cujo anteprojeto já está pronto desde o início da construção do parque, mas que até agora não foi posto em prática". ${ }^{44} \mathrm{E}$ seguiu não sendo.
39. Cf. Rosa Grena Kliass (1993, p. 165).

40. Cf. Processo 6.448/1955 - Arquivo Histórico de São Paulo.

41. Ibidem.

42. Cf. Recuperação do Parque Ibirapuera (1961).

43. Ao gabinete do prefeito, instalado no antigo Palácio das Nações desde janeiro de 1956, já se somavam quase todas as secretarias municipais (Finanças, Obras...), lembrando que $\mathrm{O}$ antigo $\mathrm{Pa}$ lácio da Agricultura já havia sido ocupado pelo Departamento Estadual de Trânsito (Detran) em 1959.

44. Cf. Ibirapuera vai ser restaurado (1965). 
45. "O Ato Institucional $\mathrm{n}^{\circ}$ 5, AI-5, baixado em 13 de dezembro de 1968, durante o governo do general costa e Silva, foi a expressão mais acabada da ditadura militar brasileira (1964-1985). Vigorou até dezembro de 1978 e produziu um elenco de ações arbitrárias de efeitos duradouros. Definiu o momento mais duro do regime, dando poder de exceção aos governantes para punir arbitrariamente os que fossem inimigos do regime ou como tal considerados”. Cf. Maria Celina D'Araujo (s.d.).

46. CF. Em 30 dias Burle Marx diz o que a cidade precisa fazer (1973).

47. Ibidem.

48. Ibidem.

49. Ibidem.
Com a instauração do regime ditatorial no país, em 1964, o território do parque acabou por consolidar-se não apenas como lócus de poder, mas também como arena para realizações políticas e de grandes obras viárias. Em 1968, foi inaugurada a nova sede da Assembleia Legislativa, erguida sobre o aterro de um dos lagos do parque. Nesse mesmo ano, em que foi instaurado o Al-5, ${ }^{45}$ que ampliava os poderes dos líderes militares no país, expandiu-se a zona militar existente no entorno do parque, com a transferência do Quartel-General do II Exército para uma porção vizinha àquela em que se ergueu a Assembleia. Em janeiro de 1969, São Paulo completava 415 anos inaugurando a Avenida 23 de Maio, que passou a ligar o centro à região do parque e que entrecortou o território do Ibirapuera, fragmentando, ainda mais, uma extensa área verde e erigindo uma barreira quase intransponível entre o parque e parte dos bairros lindeiros e que hoje já soma 18 pistas de automóveis.

Paradoxalmente a essas violações ao parque, a carência de áreas verdes na cidade passou a ser uma preocupação central das autoridades em meados da década de 1970, período de intensa urbanização e verticalização da cidade. Em 1974, o prefeito Miguel Colasuonno (1973-1975) anunciou promessas de revitalização no lbirapuera, trazendo de volta, para tanto, os "dois autores" do projeto original, um na sequência do outro. Primeiramente, às vésperas dos 20 anos do parque, Burle Marx foi convocado para elaborar projeto não apenas para - Ibirapuera, mas para as principais áreas verdes da cidade. $\bigcirc$ jornal $\bigcirc$ Estado de S. Paulo anunciou que:

O parque do Ibirapuera será reestruturado, as marginais ajardinadas, o Horto Florestal reformulado e as margens da represa de Guarapiranga arborizadas. Tudo isso ficará a cargo de Burle Marx, que, apesar de ter chegado ontem ao gabinete do prefeito Miguel Colasuonno sem saber especificamente do que se tratava, saiu meia hora depois com um prazo de 30 dias para elaborar as propostas das principais medidas da nova política de áreas verdes. ${ }^{46}$

Embora não tivesse tido o seu projeto para o parque executado na década de 1950, o paisagista era visto naquele momento pelo prefeito como uma possível esperança para a revitalização das áreas verdes da cidade, e especialmente a do lbirapuera, considerado o "primeiro lugar da escala de prioridades da prefeitura." 47 Burle Marx sobrevoou de helicóptero todas as áreas que seriam afetadas e adiantou que o lbirapuera passaria "por modificações substanciais, porque sua função [inicial] - que era abrigar exposições - fora mudando através dos anos e o parque tornara-se um local de entretenimento e lazer". ${ }^{48}$ Dava como exemplo bem-sucedido o já referido Parque do Flamengo, no Rio, que havia sido "criado com aquário, restaurantes populares, campos para basquetebol e futebol, teatro de marionetes e conchas acústicas". ${ }^{49}$ 
No estudo preliminar (Figura 8) assinado pelo paisagista Roberto Burle Marx e pelos arquitetos associados Haruyoshi Ono e José Tabacow, o plano para o Ibirapuera previa a utilização de edificações já existentes e sugeria novas áreas e construções para a implantação de restaurantes, aquário, campos esportivos, campo para adestramento de cães, bochas, playgrounds, escolinha de trânsito, patinação, patinação no gelo, teatro ao ar livre, gaiola para pássaros, sanitários e vestiários, ripado para exposições, pequenas ilhas sob os lagos, pedalinhos e plantas aquáticas, com áreas para picnic e estacionamento - como consta na legenda do projeto (Figura 9).
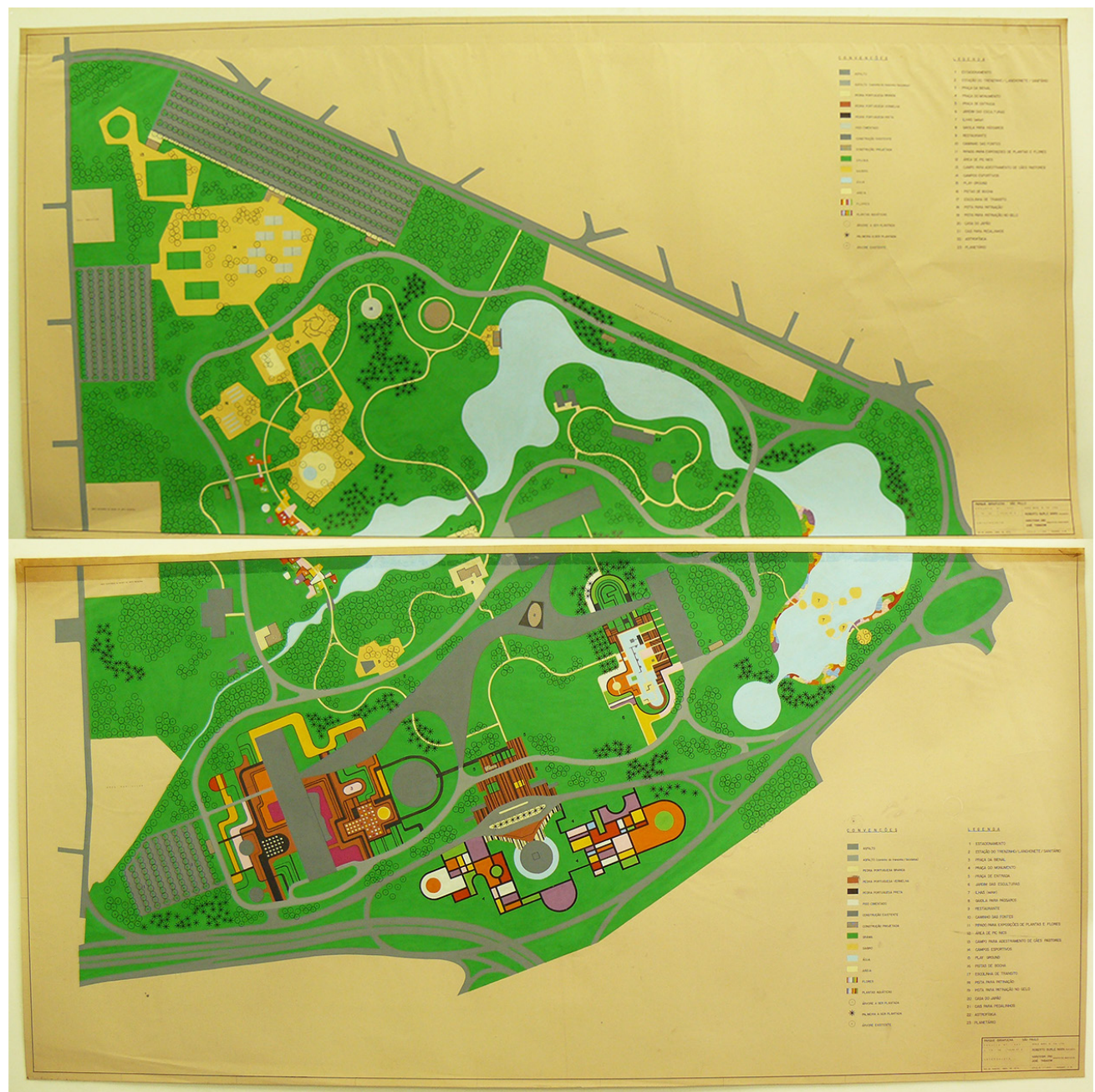

Figura 8 - Roberto Burle Marx. Estudo preliminar para o Parque Ibirapuera, 1974. (C) Escritório de Paisagismo Burle Marx. 

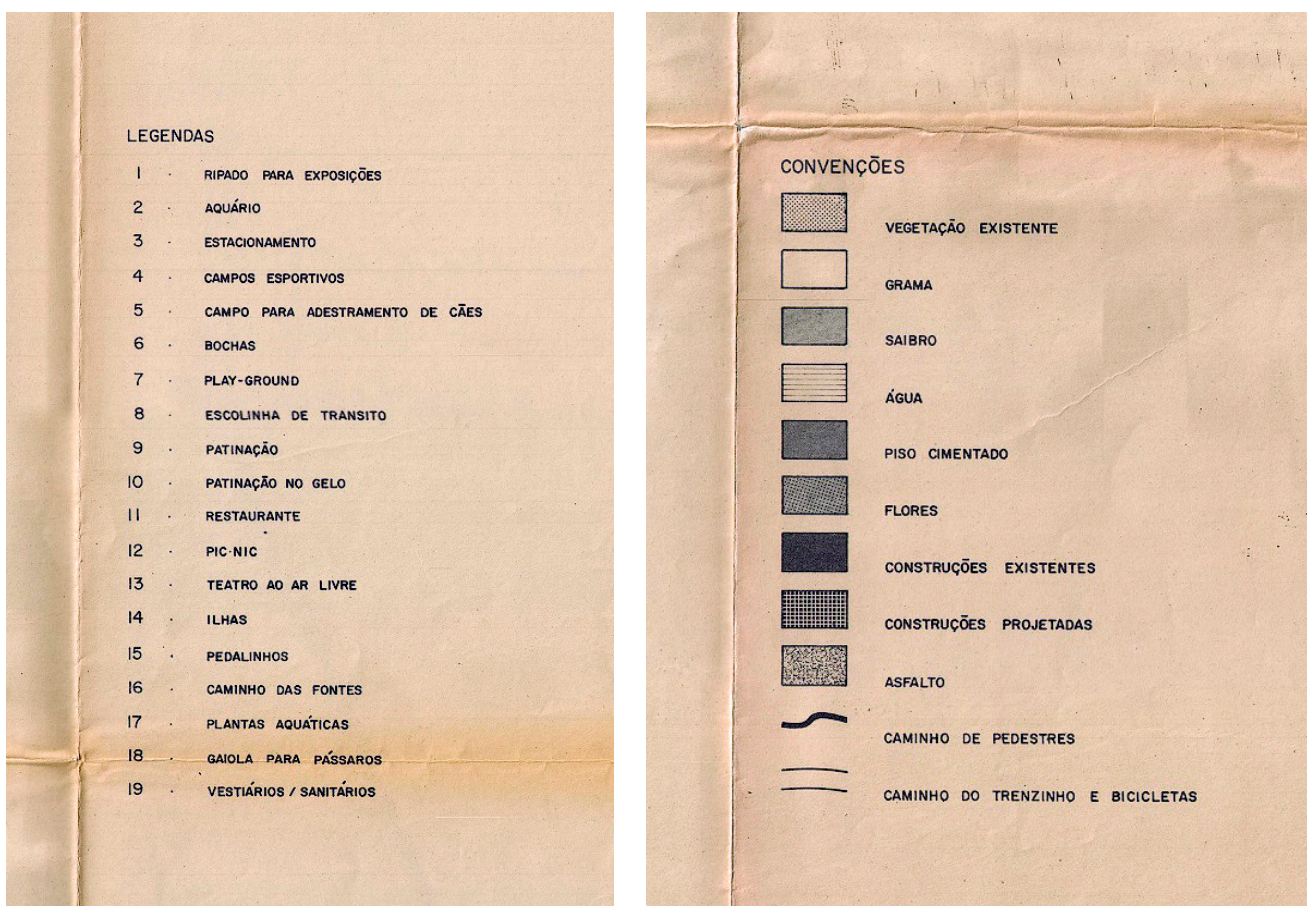

Figura 9 - Legendas e Convenções do Estudo Preliminar - Parque Ibirapuera. Fevereiro de 1975. Roberto Burle Marx (paisagista) e arquitetos associados Haruyoshi Ono e José Tabacow. (C) Escritório de Paisagismo Burle Marx.

Burle Marx trabalhou com sua equipe durante o ano de 1974 em diversos projetos para o Ibirapuera. As plantas levantadas no arquivo do Escritório de Paisagismo Burle Marx \& CIA, no Rio de Janeiro, datadas de fevereiro a outubro de 1974, revelam que, além do projeto geral para o parque, chegaram a ser desenvolvidos outros estudos mais detalhados, como um "jardim da Bienal" (julho), um projeto para a "praça de entrada e jardim das esculturas" (agosto) e, inclusive, um "Projeto Jardim do Obelisco" (maio), que propunha um espelho d'água ao redor do Monumento ao Soldado Constitucionalista de 1932 (o "Obelisco"), que se localiza entre o fim da Avenida 23 de Maio e o parque e demarcava o seu acesso principal (portões 1 e 2).

A proposta paisagística retomava a inserção de jardins no entorno dos edifícios, proposta em 1953, por meio da construção de canteiros geométricos e de plantas com cores contrastantes, mas, dessa vez, em vez dos 14 parterres do antigo projeto, privilegiava-se o entorno do pavilhão da Bienal (criando uma "Praça da Bienal" entre esse edifício e o Pavilhão Lucas Nogueira Garcez, hoje apelidado de Oca, o pavilhão da prefeitura (que receberia um "Jardim das Esculturas") e o Monumento ao Soldado Constitucionalista de 1932, para o qual se propunha a 
"Praça do Monumento", que, junto com a "Praça de Entrada", evidenciaria o acesso principal ao parque.

Diferentemente do projeto de 1953, o foco passava a ser dado aos espaços de lazer e às práticas esportivas, concentradas principalmente no extremo oposto ao do conjunto arquitetônico, área que não havia recebido tratamento no projeto anterior. Haveria, então, dois setores no parque: um cultural e administrativo, do lado dos pavilhões, e um recreativo, depois do lago (Figura 8). As áreas para estacionamento foram previstas em três zonas periféricas, o que proibiria o acesso e a circulação de veículos motorizados, sanando um dos principais problemas que o parque enfrentava na época e continua a enfrentar até o presente. Seria apenas permitida a circulação de um "trenzinho" nos recintos do parque.

Burle Marx apresentou o seu novo anteprojeto em abril de 1974, defendendo a ideia de que o parque deveria ser devolvido aos pedestres e ressaltando que "de escravo o automóvel passou a senhor, com exigências cada vez maiores e inadiáveis". Preconizando a construção de quadras de esportes e playgrounds para recreação e lazer dos usuários, dizia ainda acreditar que a vegetação proposta no novo plano humanizaria o conjunto. ${ }^{50}$

$\bigcirc$ projeto chegara com um orçamento estimado em 9 milhões de cruzeiros, valor três vezes mais alto do que o previsto pelo prefeito Colasuonno. Na semana seguinte, o jornal Última Hora propunha-se ao debate: "É viável o novo Parque Ibirapuera de Burle Marx?" Quem respondia era o arquiteto Paulo Mendes da Rocha, contextualizando bem a questão:

Construir um jardim é para a cidade de São Paulo uma aventura extraordinária. $\bigcirc$ jardim do lbirapuera nós estamos fazendo há 20 anos. Ocupado com um projeto para as comemorações do IV Centenário da cidade, ganhou a condição de escapar das indefinições estranhas à arquitetura e à vida urbana. Como todo modelo de arquitetura, sintetiza uma hipótese concreta de uso que a cidade inventava: conjunto de edifícios modernos, com espaços e desenho de grande significado na sua poética, para a população paulista exibir o resultado do seu trabalho. (...) A história do parque está cheia de percalços e episódios, que são, se se quiser, uma amostra de alguns dos mais curiosos aspectos da vida dessa cidade. Enquanto uma especulação imobiliária violenta não deixa escapar o metro quadrado, o parque fica com seus quilômetros como desafio. (...) Uma cidade civilizada vê no Edifício Público a mais alta expressão de sua época. (...) Construído o lbirapuera, com uma qualidade que o Poder Público há muito não imaginava para suas obras, de acordo com os projetos de Oscar Niemeyer, nada mais natural que ocupá-lo para as maiores emergências. (...). Mas, uma vez ainda, a urgência e a emergência dessa cidade, nesse gesto, passou a depredar o Parque. Os prédios atulharam-se de biombos e ambientes de papeIão, os grandes espaços e a luz assustam a província. Os jardins viraram tapera. Tentar agora recuperar alguns aspectos de sua natureza inicial é uma última perspectiva. Se para tanto se precisa também do prestígio de um artista como Burle Marx, tanto melhor, mostra, entre nós, o prestígio das artes e da intervenção criadora. Nenhum botânico contemporâ-
50. Cf. Ibirapuera só área de lazer (1974). 
51. Cf. É viável o novo Parque Ibirapuera de Burle Marx? (1974).

52. Cf. Prefeitura pode abandonar projeto do novo Ibirapuera (1974).

53. O Ibirapuera ainda um parque inacabado (1975). neo sabe melhor que ele riscar um jardim. É essa sua dimensão como artista. Transferir as Repartições Públicas para prédios próprios, projetados em local urbanisticamente adequado e com desenho atual, destinar os edifícios à Bienal de Artes Plásticas, a Museus. Organizar um grande restaurante popular às margens do Lago, como estava no projeto original. Construir o Teatro. Modernizar os jardins, corrigir o plantio das árvores. Tirar o tráfego de automóveis, adequar o uso da área ao lazer da população, correndo todos os riscos necessários é uma natural providência do Poder Municipal. ${ }^{51}$

No entanto, três meses depois, uma manchete d'O Estado de S. Paulo já apontava mudança de planos: "Prefeitura pode abandonar projeto do novo Ibirapuera". Segundo o jornal, alguns técnicos da prefeitura achavam "que as propostas de Burle Marx eram faraônicas, muito dispendiosas, excessivamente sofisticadas e distanciadas das necessidades de lazer do paulistano". Considerado inexequível pelo corpo técnico, o projeto do paisagista propunha, inclusive, uma grande pista circular para patinação no gelo. As estimativas para as obras de recuperação do lbirapuera naquele momento já giravam em torno de 25 milhões de cruzeiros, dos quais 10 milhões seriam para a "construção de galerias pluviais para o controle da polvição" dos lagos e 12 milhões a "prédios pré-moldáveis, para a transferência dos departamentos da prefeitura que funcionam no Ibirapuera". Com isso, restavam apenas 3 milhões para as reformas do parque, apenas um terço do valor proposto pelo paisagista, o que inviabilizava o projeto de Burle Marx, uma vez mais. ${ }^{52}$

Colasuonno havia dado o prazo de janeiro de 1975 para a conclusão da reforma no parque e no dia 22 daquele mês $O$ Estado de $S$. Paulo constatava que já haviam sido "plantadas mais 968 árvores", além de "150 mil m² de novos gramados e a recuperação de outros 200 mil m²", ao custo de " $\mathrm{Cr} \$ 1,8$ milhão". Mas, com a conclusão prevista para o mês seguinte, muito pouco do prometido havia sido feito:

E, mais uma vez, a data estipulada pelo prefeito não está sendo cumprida. As obras contratadas ainda estão em fase de execução, os $\mathrm{Cr} \$ 42$ milhões sendo gastos lentamente (...) As quadras de bocha, o jardim das esculturas, a escolinha de trânsito, os restaurantes e campos esportivos, as projeções ao ar livre, o trenzinho nas alamedas e os estacionamentos, nada está sendo implantado. Embora todas essas obras constem do projeto elaborado por Burle Marx, que custou Cr\$320 mil. . $^{53}$

No final daquele mês de janeiro, o prefeito recebeu Oscar Niemeyer, que havia sido convidado dois meses antes para voltar a atuar no Parque Ibirapuera. O prefeito esperava que o arquiteto, "que foi idealizador do primeiro grande parque de São Paulo", ao "verificar as distorções" ocorridas desde a implantação do parque, pudesse orientar e "dar cobertura profissional 
quanto à devolução total do lbirapuera ao povo, como símbolo da humanização da cidade de São Paulo". ${ }^{54}$

Já Niemeyer defendia que "o parque se destinava a ser um grande centro de culturas, com salas para conferências e exposições", e que não havia razão para a instalação das repartições da prefeitura nos pavilhões, que estas deveriam ser retiradas. Lamentou a ausência do auditório, que, não construído, havia dado ao parque "um aspecto indefinido", identificando aí a origem das distorções. Assinalou ainda que "São Paulo estava se transformando numa verdadeira selva de concreto" devido à "especulação imobiliária, a maior responsável pela destruição das poucas áreas verdes". E foi sucinto na sua verificação:

O Ibirapuera se resume hoje numa série de lotes cortados por circulação de veículos; os prédios estão adulterados; a marquise completamente ocupada; a finalidade da área acabou se desvirtuando, o que é lamentável. O lbirapuera é atualmente um recanto da cidade com circulação de veículos por todos os lados, quando a ideia era justamente o contrário, ou seja, a implantação de um grande jardim. ${ }^{55}$

É estranho que o arquiteto se refira à ideia do parque como a "implantação de um grande jardim", já que, como visto, na década de 1950 os jardins receberam um tratamento subsidiário e incompleto, representando apenas $0,1 \%$ do total de 400 milhões de cruzeiros investidos na construção do parque, em concreto armado, situação que, como vimos, parece ter sido alcançada com a colaboração de Niemeyer ao ajustar-se ao projeto paisagístico de Teixeira Mendes. A "revisão" que Niemeyer faria no "plano diretor" do Ibirapuera a pedido de Colasuonno acabou, no entanto, não se efetivando, pois houve apenas "uma reunião no Rio de Janeiro entre o arquiteto e os técnicos da prefeitura, e não foi assinado nenhum contrato para a elaboração desse plano". 56

mandato de Colasuonno terminara e o novo prefeito, Olavo Setúbal (1975-1979), declarava haver colocado "de lado a aplicação imediata do plano paisagístico de Burle Marx para o Parque Ibirapuera", pois "uma reformulação física e de uso do parque, nos termos propostos, é trabalho para muitos anos, em vista das dificuldades a superar e das verbas exigidas". $\bigcirc$ orçamento do projeto, de 9 milhões de cruzeiros, estimado quando entregue à administração anterior, já era da ordem de 37 milhões naquele momento. ${ }^{57}$

Após tal recusa, Burle Marx só voltaria a desenvolver projetos para o Ibirapuera na década de 1990, e as dificuldades do paisagista em efetivar seus projetos no parque seriam, dessa vez, parcialmente superadas.
54. Ibidem.

55. Ibidem.

56. Ibidem.

57. Cf. Ibirapuera terá sua nova reforma só a longo prazo (1975). 
58. Os túneis acabaram sendo retomados e inaugurados na gestão de Paulo Maluf (1993-1996), após a gestão de Luiza Erundina.

59. Ver Agora, o Ibirapuera (1991).

60. Ver Secretaria... (1992), Conselho... (1992).

61. Cf. Vicente Viladarga (1991).

62. Cf. O verde em obras (1992).

\section{ANOS 1990: ÚLTIMA TENTATIVA, SUCESSO PARCIAL}

No contexto da nova ordem liberal-democrática no país instaurada após o término da ditadura militar, em 1985, o Ibirapuera chegou à década de 1990 sob amplo debate, gerado pelas obras dos túneis projetados no segundo mandato de Jânio Quadros como prefeito de São Paulo (1986-1 1988). Privilegiando-se uma vez mais o concreto e o automóvel, dessa vez no subterrâneo do parque, a proposta era construir túneis exclusivos para automóveis, conectando o bairro elitizado do Morumbi à Avenida 23 de Maio. Manifestações contrárias às obras acabaram por fazer com que o órgão estadual de defesa do patrimônio cultural, - Condephaat, abrisse um processo de tombamento do lbirapuera, o que fez com que as obras fossem embargadas. ${ }^{58}$

Em 11 de janeiro de 1991, a prefeita Luiza Erundina (1989-1992), que havia paralisado a construção dos túneis da gestão de Jânio Quadros, sancionou o projeto de lei do vereador Marcos Mendonça, de 1989, estabelecendo municipalmente a preservação do Parque lbirapuera, declarando-o como um "patrimônio histórico, cultural e ambiental da cidade". ${ }^{59}$ A lei municipal previa a retirada das sedes administrativas do lbirapuera até dezembro de 1992, quando houve, de fato, a transferência do gabinete da prefeita para o Palácio das Indústrias, no Parque Dom Pedro II, já no final de seu mandato. Além disso, o Condephaat aprovou o tombamento estadual do parque em 25 de janeiro de 1992, criando uma nova instância de aprovação para o caso de alterações nele. ${ }^{60}$

Na iminência da saída da sede da prefeitura do parque, começaram a ser realizadas diversas pesquisas e consultas públicas sobre o futuro do lbirapuera e foram surgindo inúmeras especulações e propostas para os novos usos que os pavilhões passariam a ter. $\bigcirc$ Jornal da Tarde anunciou com um antecipado entusiasmo: "O verde vence o concreto no Ibirapuera", sinalizando que o lazer tornava-se uma prioridade. Uma primeira ideia, vinda da Secretaria Estadual da Cultura, que tombara o parque e que já pleiteava um espaço seu nele, era que a antiga prefeitura - o pavilhão Manuel da Nóbrega - se transformasse em um "centro ecológico", com "cursos e exposições voltados para o meio ambiente". ${ }^{61}$

Iniciando uma prática que se tornaria recorrente nas décadas seguintes - a iniciativa privada tomando as rédeas do parque -, o programa Mais Ibirapuera para você foi lançado em 1992 com a proposta de "revitalizar e oferecer novas opções de diversão e uma estrutura física mais adequada". 62 Patrocinado pelo Banco Real e pela Rede Globo de Televisão/Fundação Roberto Marinho, e com o apoio da prefeitura, o projeto trouxe mais uma vez de volta ao lbirapuera, aos seus 40 anos, o autor dos dois projetos paisagísticos não implantados nas décadas 
de 1950 e 1970, Roberto Burle Marx. O ponto de partida desse programa foi uma pesquisa realizada entre 7.800 frequentadores, divulgada pela revista Veja São Paulo, com os seguintes números:

Entre os entrevistados, $51 \%$ disseram que vão ao parque para praticar cooper, andar ou correr. Só $11 \%$ admitiram que, à sombra das árvores, se dedicam a outro esporte: a paquera. Em segundo lugar, ficou a opção passear (47\%), seguida por apreciar a natureza $(33 \%) .63$

O Mais Ibirapuera para você, que era também uma proposta de marketing cultural que deveria beneficiar seus patrocinadores, previa a criação de três novos playgrounds (Figura 10), a "sinalização com mapas completos do parque nos portões e setas indicativas de banheiros e lanchonetes", a melhoria do restaurante e das três lanchonetes. Além disso, propunha a restauração do Viveiro Manequinho Lopes, que teria "plantas ornamentais da Amazônia e outras cinco estufas de flores como bromélias ou orquídeas", com o projeto paisagístico a cargo de Burle Marx. ${ }^{64}$

Dessa vez, a proposta preliminar de Burle Marx foi ainda mais ousada e causou polêmicas ao propor mudar o "horto", o Viveiro Manequinho Lopes, "para outro ponto, mais afastado da cidade, e transformar o atual espaço de cultivo de árvores em ampla área de lazer". A prefeita Luiza Erundina, que era simpática à presença de Burle Marx, disse, no entanto, que pretendia "discutir melhor a ideia de mudança do horto", além de declarar que, como o parque seria oficialmente tombado em questão de dias, "a prefeitura não poderá mais promover nenhuma inovação arquitetônica ou redistribuição do espaço que desfigure a área". 65

Diferentemente das duas vezes anteriores, algumas ideias do novo projeto de Burle Marx foram, dessa vez, finalmente realizadas, enquanto outras o foram apenas parcialmente. Grande atenção foi dada à reforma do Viveiro Manequinho Lopes, o mesmo que antes seria retirado, mas que acabou por contar com a recuperação de estufas quebradas e a construção da Praça do Viveiro (Figura 11) ao redor da antiga Serraria. Parte das propostas para o parque não foi implantada ou sofreu mudanças (Figura 12), como, por exemplo, a construção da ciclovia, "uma das principais reivindicações dos frequentadores", apontada nas pesquisas. Uma "ciclovia experimental" chegou a ser implantada em janeiro de 1993, mas teve vida curta. Inaugurada com faixas pintadas no meio das vias, como previsto no projeto de Burle Marx (Figura 13), a ciclovia não funcionou, pois, segundo os jornais, "não acabou com os problemas entre ciclistas e pedestres". Seria, então, desativada e a nova proposta era substituíla por uma "ciclovia periférica, passando pelos locais menos procurados do parque" 60 (o que também não se efetivou).
65. Cf. Burle Marx afasta Niemeyer da reforma do Parque do Ibirapuera (1992).

66. Cf. Ciclistas perdem a pista exclusiva no Ibirapuera (1993). 


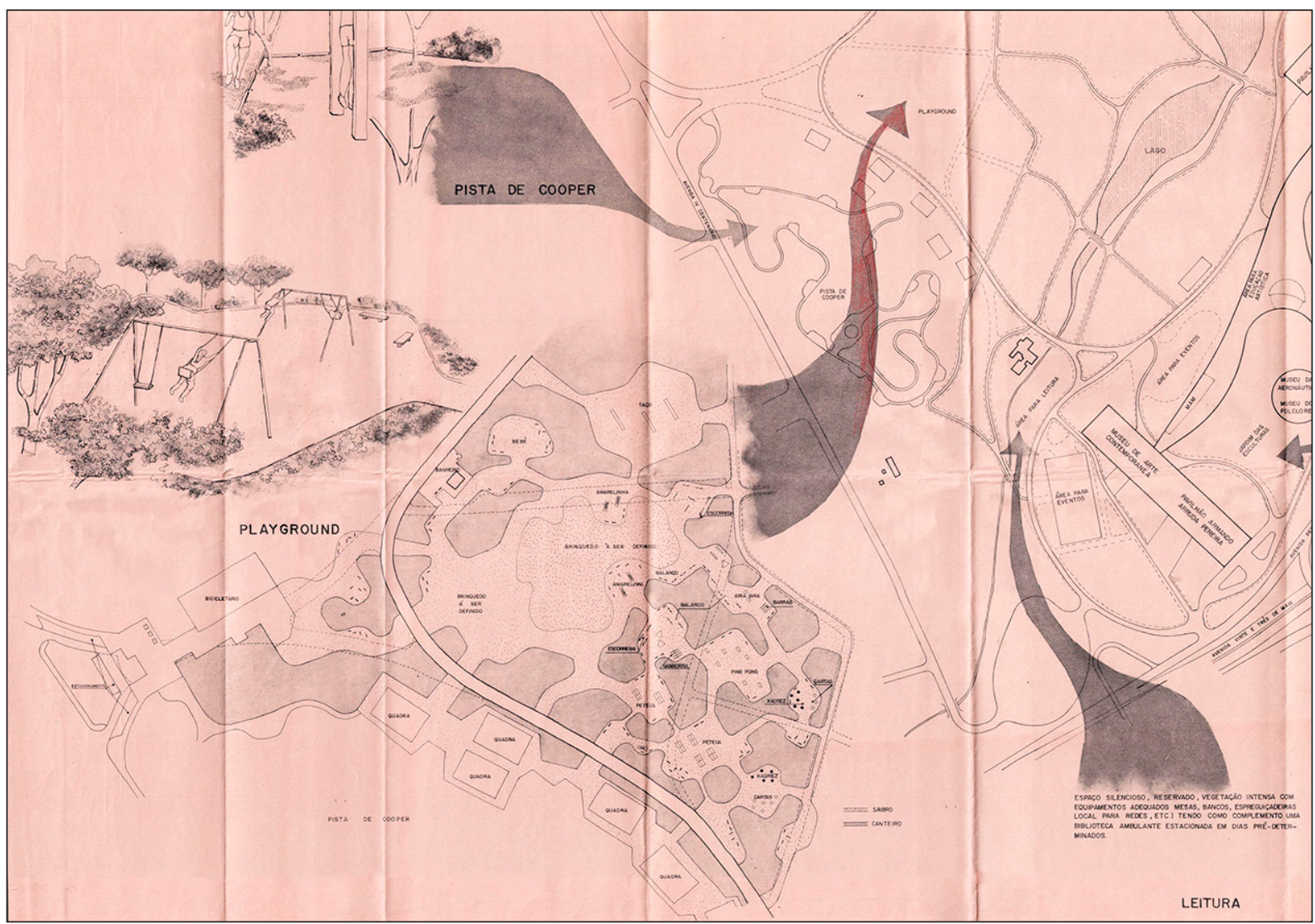

Figura 10 - Detalhe de Playground (flecha central) e Espaço de Leitura (flecha à direita) - Projeto Paisagístico Parque Ibirapuera. São Paulo, out.-dez. 1992. (C) Escritório de Paisagismo Burle Marx.

Figura 11 - Detalhe da Praça de Acesso ao Viveiro Manequinho Lopes - Projeto Paisagístico Parque Ibirapuera. São Paulo, out.-dez. 1992. ( Escritório de Paisagismo Burle Marx.

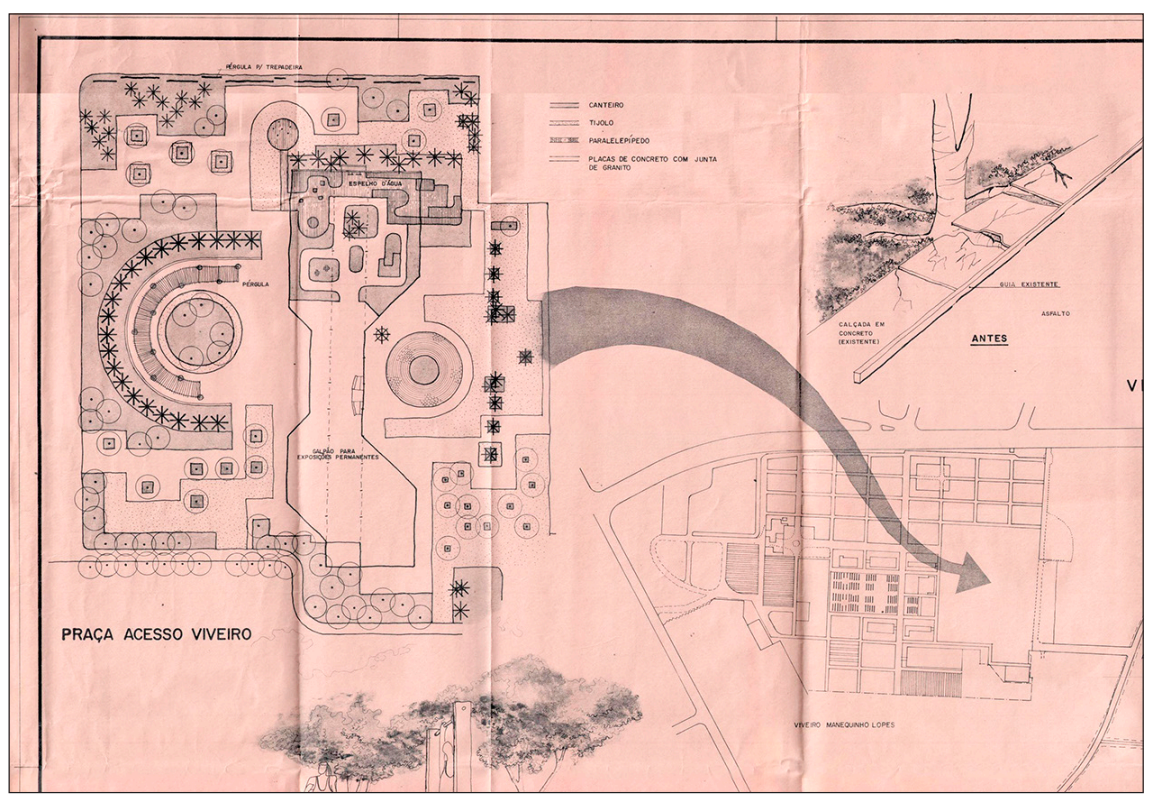




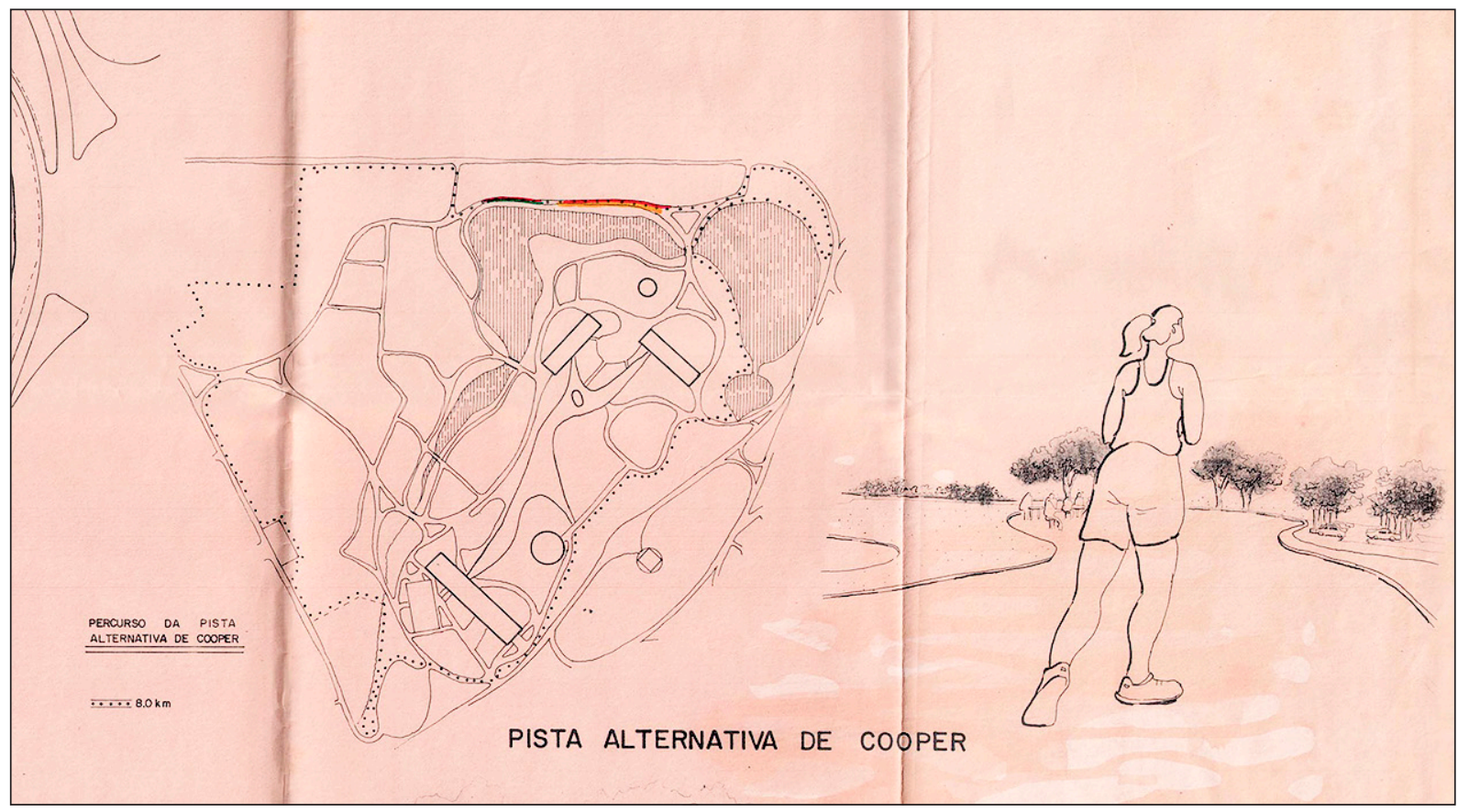

Figura 12 - Detalhe da Pista Alternativa de Cooper (não realizada) - Projeto Paisagístico Parque Ibirapuera. São Paulo, out.-dez. 1992. (C) Escritório de Paisagismo Burle Marx.

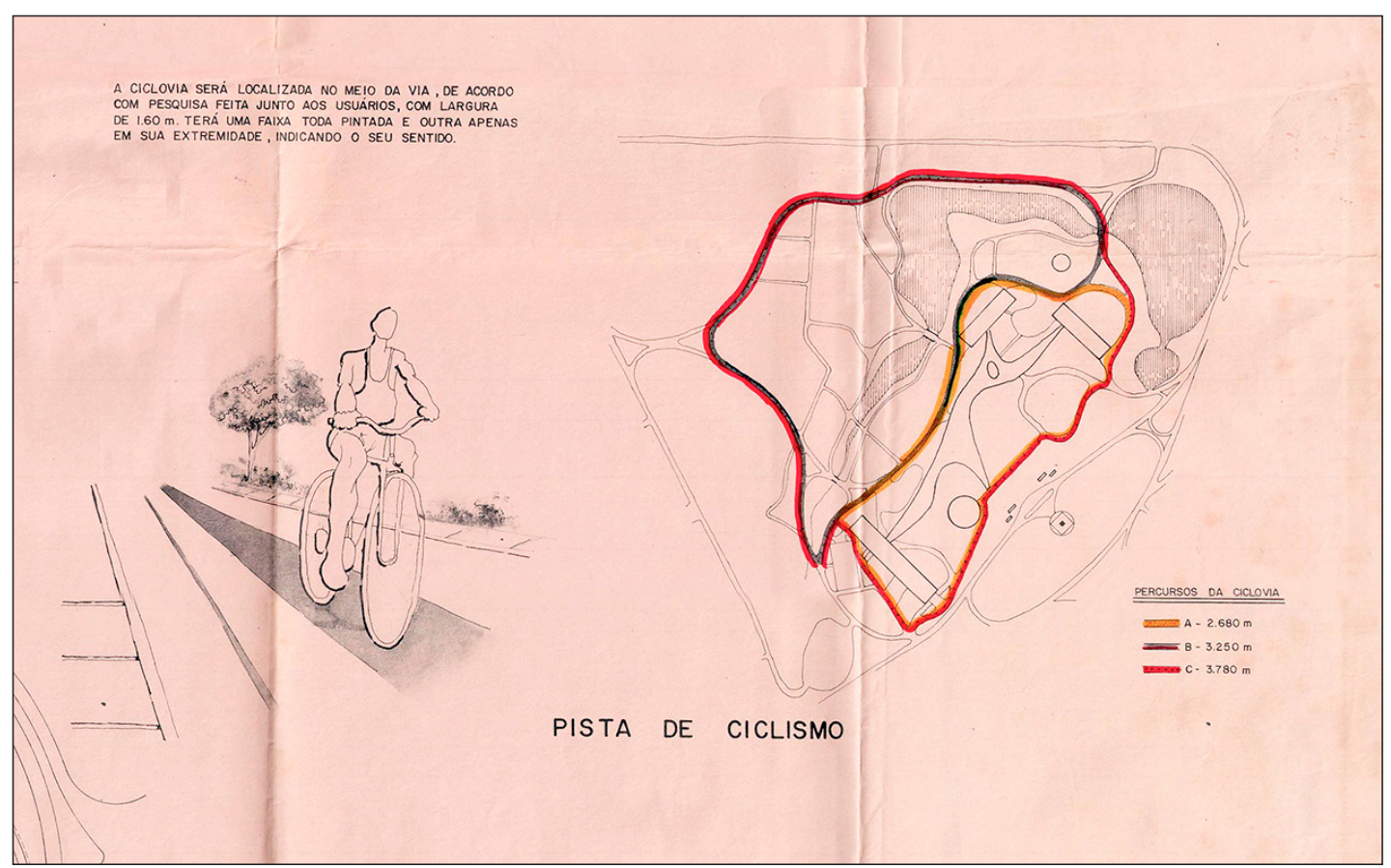

Figura 13 - Detalhe da Ciclovia - Projeto Paisagístico Parque Ibirapuera. São Paulo, out.-dez. 1992. (C) Escritório de Paisagismo Burle Marx. 
67. Cf. Roberto Burle Marx (2009).

68. Obras de Amílcar de Castro, Emanoel Araujo, Felicia Leirner, Franz Weissmann, Mario Cravo Junior, entre outros. $\bigcirc$ "produto" mais anunciado do Mais Ibirapuera para você foi mesmo o Jardim das Esculturas ao redor do Museu de Arte Moderna (MAM), definido assim por Burle Marx: "Um espaço para estimular na comunidade a prática da convivência artística, divulgando as obras dos nossos artistas e valorizando a nossa cultura". b7 $^{7}$ Tal jardim se estenderia entre o MAM, a Fundação Bienal e os museus da Aeronáutica e do Folclore (Figura 14), que, naquele momento, dividiam o Pavilhão Lucas Nogueira Garcez (Oca). Com as esculturas do MAM ${ }^{68}$ expostas ao ar livre, entre árvores e palmeiras existentes, foi sugerida nova vegetação entre caminhos traçados com britas, pedriscos, cimentados e gramados. $O$ Jardim das Esculturas foi inaugurado no dia 8 de junho de 1993, um ano antes da morte de Burle Marx, em 4 de junho de 1994.

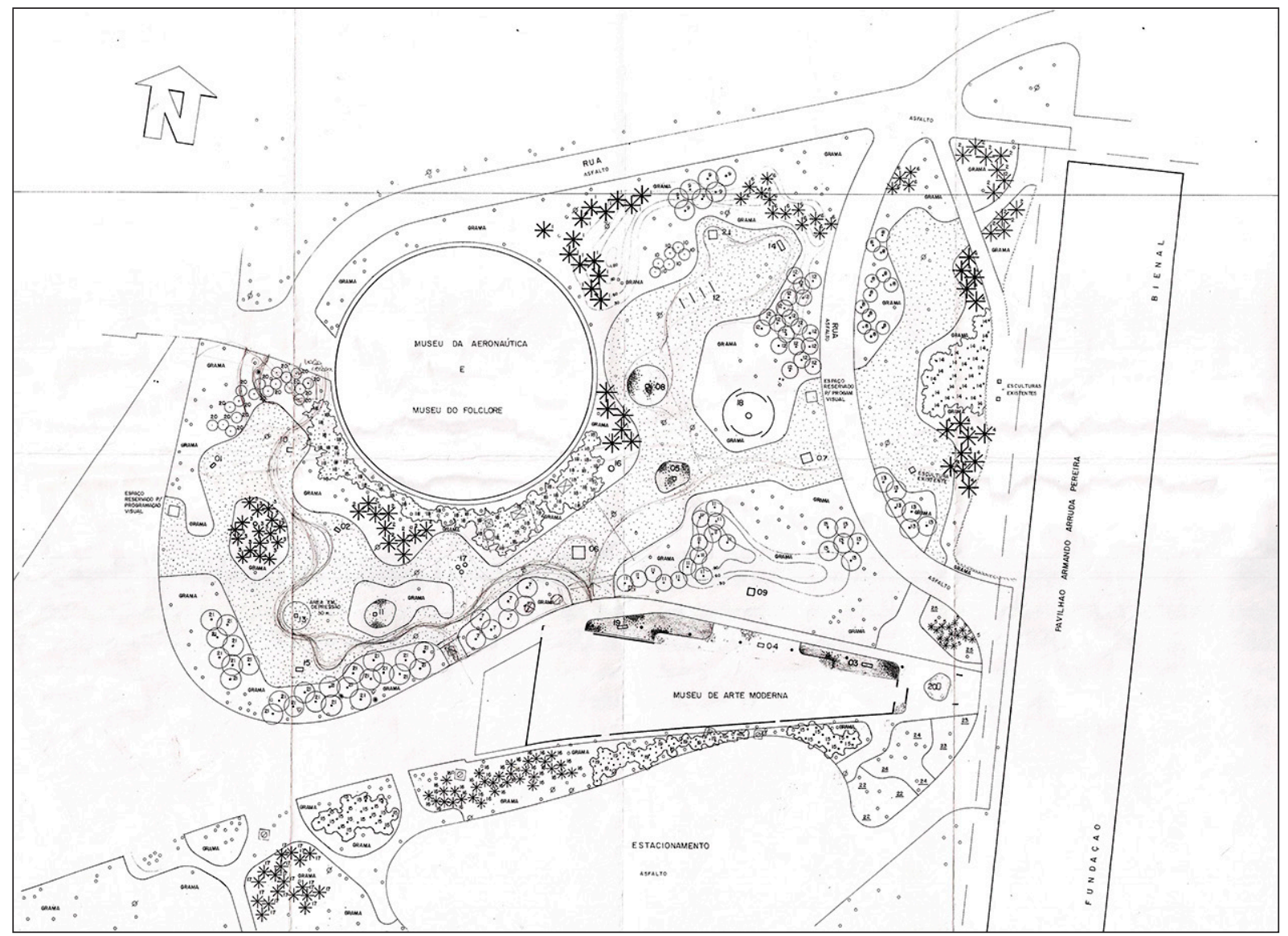

Figura 14 - Projeto Paisagístico - Jardim das Esculturas, mar. 1993. (c) Escritório de Paisagismo Burle Marx.

Após o falecimento de Burle Marx, o Jardim das Esculturas passaria ainda por duas reformas na década de 2000, já conduzidas pelo seu sócio no escritório 
de paisagismo, Haruyoshi Ono. Vale lembrar que o Jardim das Esculturas, embora situado não exatamente no mesmo lugar e com esse nome, estava previsto tanto no projeto de 1974 como também no original de 1953, descrito por Claude Vincent na revista $B A C$ :

Perto do Museu de Arte, será colocado um jardim especialmente planejado para abrigar esculturas, facilitando a observação destes volumes projetados no espaço. Haverá muros vivos, de plantas, e outros de pedra, de alturas variadas, para acentuar o sentido espacial e para isolar uma estátua das outras. ${ }^{69}$

Embora o Jardim das Esculturas fosse a "vitrine" do projeto Mais Ibirapuera para você, ele consumiu apenas 70 mil dólares do valor total do projeto, que, segundo a revista Veja São Paulo, alcançou a cifra de 3 milhões de dólares, gastos, segundo a divulgação dos patrocinadores, com diversas pequenas intervenções que não chegaram a alterar significativamente a fisionomia do parque, definida na década de 1950.

\section{A ARTE DA PAISAGEM, EM MEMÓRIA}

Desde que foi inaugurado, muitas disputas ocorreram no Parque Ibirapuera. Como vimos, a falta de uma definição clara do uso de seus pavilhões após os festejos do IV Centenário e de um projeto paisagístico que obrigasse manutenções frequentes fez com que o Ibirapuera se consolidasse, nos anos conseguintes à sua inauguração, como sede administrativa, perdendo grande parte de seu espaço para novas construções e avenidas. Não houve espaço, ali, para a arte da paisagem de Burle Marx, que se mostrara especialmente sofisticada em seu projeto inicial.

Na ocasião da $2^{a}$ Bienal, em 1953, que pré-inaugurou o Ibirapuera, a II Exposição Internacional de Arquitetura integrou essa mostra e homenageou o alemão Walter Gropius com o grande prêmio, além de apresentar o projeto de Oscar Niemeyer e de sua equipe para o parque. Burle Marx foi premiado por dois de seus projetos de jardins particulares, pertencentes às residências de Odette Monteiro (Petrópolis, 1946) e de Walter Moreira Salles (Rio de Janeiro, 1948).

Logo após o fim daquela exposição, entre maio e junho de 1954, o paisagista realizou a sua primeira mostra internacional, com um conjunto significativo de seus projetos concebidos até então, denominada Landscape Architecture in
69. Cf. Claude Vincent (1954, p.59). 
70. Ver Landscape Architecture in Brazil... (1954).
Brazil: Roberto Burle Marx, organizada pelo Smithsonian Institute na sede da Pan American Union, em Washington, D.C. (Figura 15). Entre as 27 obras expostas, figurava em destaque no pequeno livreto da exposição o detalhe do seu "Project for Ibirapuera Park, São Paulo (not executed)". ${ }^{70}$

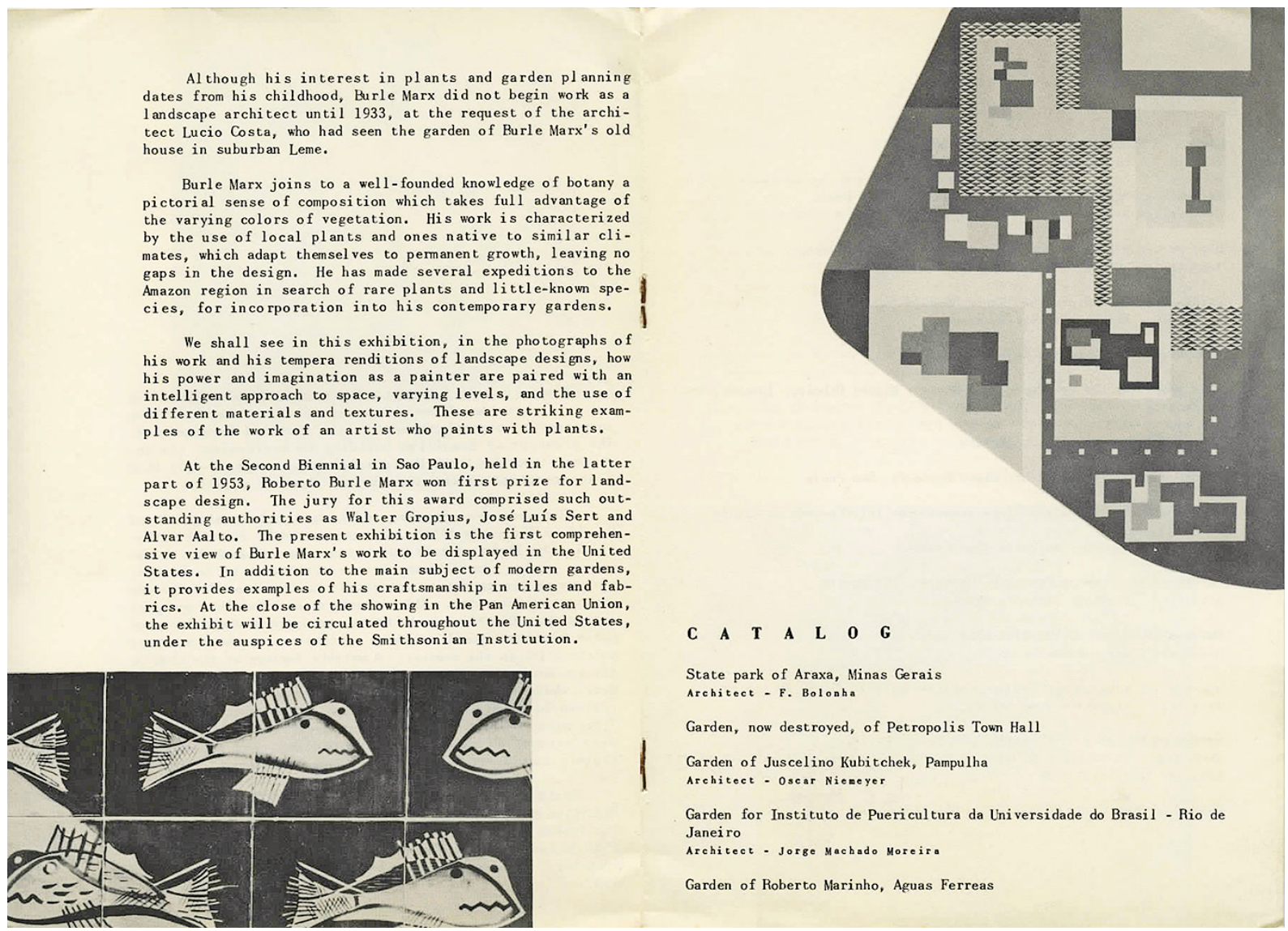

Figura 15 - Página do livreto da exposição Landscape Architecture in Brazil... (1954). Arquivo Histórico Wanda Svevo/ Fundação Bienal de São Paulo.

Embora não executado, o projeto de Burle Marx para o Ibirapuera já era considerado uma obra de arte paisagística e, como tal, foi incorporado ao acervo do Museum of Modern Art de Nova York (MoMA), passando a integrar a Architecture Collection do museu. $\bigcirc$ Detalhe $n^{\circ} 5$ (Figura 3), pintado em guache, foi adquirido pelo museu com verba do Inter-American Fund e integrou a exposição Recent Aquisitions (realizada de novembro de 1955 a fevereiro de 1956) ao lado de outras 50 obras também recém-adquiridas pelo museu, como Water Lilies, de Claude Monet, entre outras, de artistas internacionais (como Pablo Picasso, Henri Matisse, Henry Moore), em sua grande parte, também presentes naquela $2^{a}$ Bienal 
de São Paulo. ${ }^{71}$ Realizada simultaneamente à mostra das aquisições recentes do MoMA, a exposição Latin American Architecture since 1945 também incluía outro trabalho de Burle Marx, o premiado Jardim da residência Odete Monteiro, junto a projetos de Niemeyer (Igreja da Pampulha, Banco Boa Vista, Casa das Canoas) e de outros arquitetos brasileiros ${ }^{72}$ e estrangeiros, como Le Corbusier, Luis Barragan e Carlos Villanueva. Burle Marx, portanto, se fazia presente, já na década de 1950, entre os grandes nomes tanto da arte quanto da arquitetura, em duas exposições que ocorriam em paralelo num dos mais prestigiosos museus do mundo. Como ele mesmo afirmara sobre seu fluido trânsito transdisciplinar:

Não estudo os jardins em que trabalho apenas como botânico, mas também como o pintor que sempre fui. Cor, contraste, harmonia, estrutura, forma são tão importantes para mim como pintor ou como arquiteto de jardins. ${ }^{73}$

Mas o seu conjunto de desenhos para o Parque Ibirapuera receberia maior protagonismo na exposição The Unnatural Art of the Garden, realizada em 1991 (Figura 16). Katia Canton escreveu sobre a exposição para a revista IstoÉ, destacando, entre os projetos expostos, "o incrível e nunca executado projeto para o Parque Ibirapuera (1953), criado por ele junto com Oscar Niemeyer por ocasião do IV Centenário de São Paulo, com suas intricadas rampas entrecortando pequenos jardins e lagoas".74

Essa foi a primeira exposição dedicada exclusivamente à arte da paisagem realizada no MoMA, motivo pelo qual tal exposição pode ser considerada um coroamento da carreira de Burle Marx, já que ele viria a falecer no ano seguinte, e o Parque Ibirapuera nela desempenhou um papel estratégico decisivo.

Dos cinco projetos ${ }^{75}$ do autor salvaguardados pelo museu, é o do Ibirapuera o mais bem representado, com as três belas pranchas em guache, sendo que duas delas - planta geral e perspectiva - foram adquiridas precisamente para a exposição. A venda dessas pranchas para o MoMA por Burle Marx, pouco antes de seu falecimento, pode ser compreendida, portanto, como um gesto fundamental do autor: uma vez que ele nunca conseguiu implantar o projeto, ao menos o tornaria mundialmente conhecido como parte do acervo do mais prestigioso museu de arte moderna no mundo. Esse fato pode ser considerado um reconhecimento simbólico que o projeto não teve no campo real - e que o torna uma nota dissonante em sua carreira marcada pela execução de parques e jardins emblemáticos em diversas metrópoles brasileiras e do mundo. Assim, embora a relação entre o paisagista e o Parque Ibirapuera tenha atravessado quatro décadas de descompassos, sua monumentalização tardia expressou uma forma de acerto de contas com o
71. Karel Appel, William Baziotes, Paul-Émile Borduas, Fernand Léger, Émile Nolde, Lucien Freud, Isamu Noguchi, Rufino Tamayo, Max Beckmann, entre outros.

72. Oswaldo Bratke, Sergio Bernardes, Lucio Costa, Affonso Reidy, Rino Levi, Ícaro de Castro Mello, Irmãos Roberto, entre outros.

73. Cf. Burle Marx fala sobre a arte da paisagem (1954).

74. Cf. Kátia Canton (1991).

75. Entre os 17 itens relacionados a Burle Marx no acervo do MoMA, dez referem-se a seu projeto de jardins para a casa de praia do casal Burton Tremaine, de 1948 , projetada por Oscar Niemeyer em parceira com Burle Marx (não executado, o conjunto total de dez pranchas foi doado pelo casal ao museu em 1966). Entre os sete itens restantes, estão as três pranchas a guache do Ibirapuera, uma maquete da Fazenda Vargem Grande (1979-1980) também adquirida pelo Museu em 1991, a planta da Praça Duque de Caxias, no Rio de Janeiro, de 1948, doada por Phillip L. Goodwin naquele mesmo ano, além de duas aquisições mais recentes, de 2015: uma obra têxtil em algodão de 1980 e uma fotografia de Leonardo Finotti que retrata a colaboração de Burle Marx e Affonso Eduardo Reidy no Museu de Arte Moderna do Rio de Janeiro. 
passado, que preserva, em âmbito internacional, a memória de um de seus mais belos projetos paisagísticos.

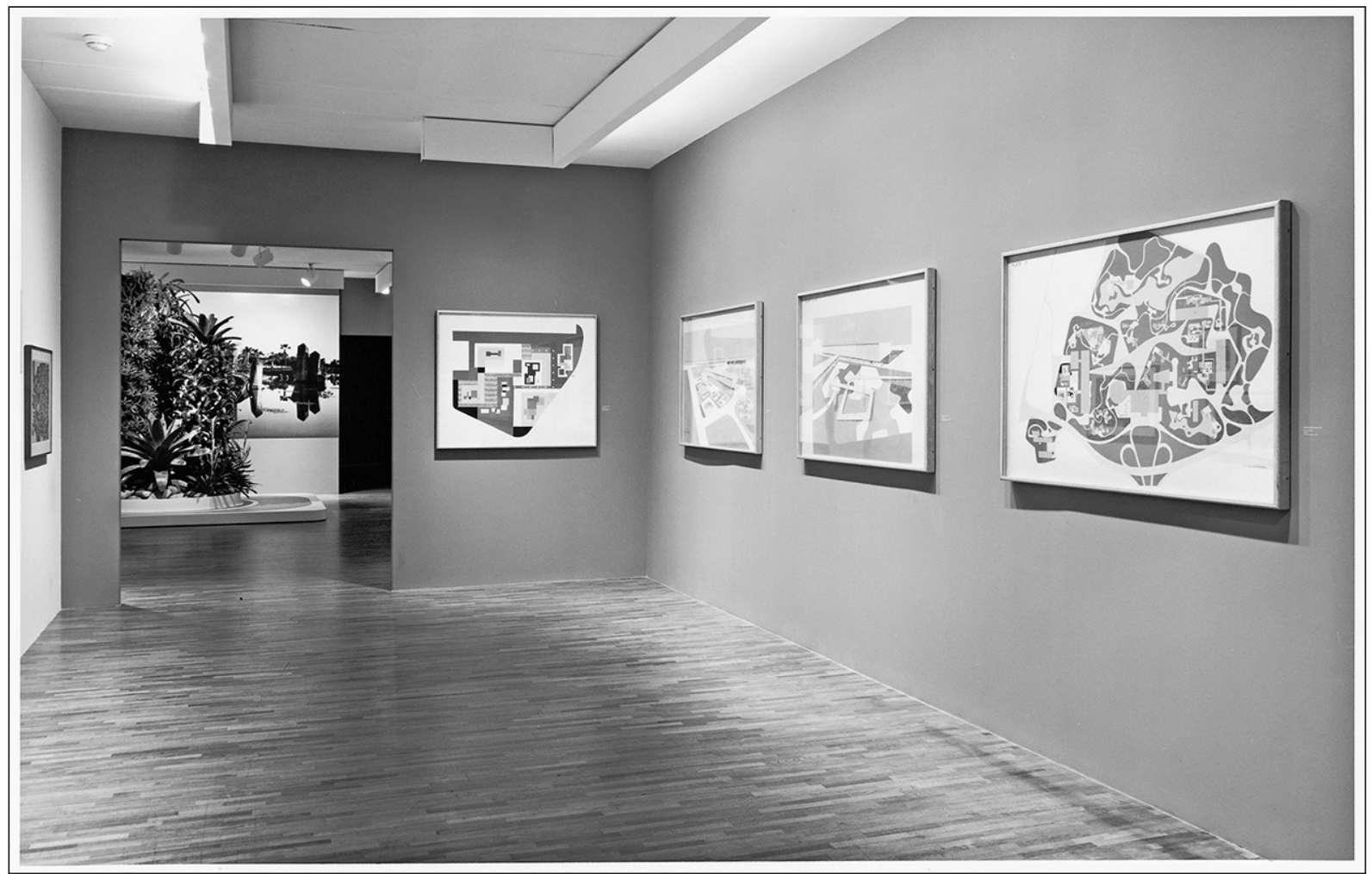

Figura 16 - Vista da exposição Roberto Burle Marx: The Unnatural Art of the Garden, no MoMA. Nova York. (23/05/1991 a 13/08/1991). Fotografia de Mali Olatunii. Revelação em prata, 6 ×9" (15.2 × 22.9cm). Acervo do, Museum of Modern Art (MoMA), Nova York, arquivo fotográfico, Cat. no.: IN 1584.2. (C) The Museum of Modern Art, New York). (c) 2017. Digital image, The Museum of Modern Art, New York/Scala, Florence. 


\section{REFERÊNCIAS}

\section{FONTES PRIMÁRIAS}

AGORA, o Ibirapuera é patrimônio histórico da cidade. Jornal da Tarde, São Paulo, 15 jan. 1991.

ALVES, Ernesto de Faria. Carta ao presidente da Comissão do IV Centenário. São Paulo, 7 fev. 1953. Arquivo Histórico de São Paulo, processo no 1.936, de 1953.

BURLE Marx afasta Niemeyer da reforma do Parque do Ibirapuera. O Estado de S. Paulo, São Paulo, 15 jan. 1992.

BURLE Marx fala sobre a arte da paisagem. Correio da Manhã, Rio de Janeiro, 23 dez. 1954.

CAMARGO, Maria Inês de. Ibirapuera fica quarentão com muita festa. O Estado de S. Paulo, São Paulo, 15 ago. 1994.

CANTON, Kátia. Éden recriado. IstoÉ, São Paulo, 5 jun. 1991.

CARDOSO, Joaquim. O conjunto arquitetônico de Ibirapuera. Brasil Arquitetura Contemporânea, Rio de Janeiro, no 2-3, p. 49-62, jan. 1954.

CENTRO cultural ainda é espaço vazio. O Estado de S. Paulo, São Paulo, 18 mar. 1993.

CHACON, Lelia. Ibirapuera pode ser tombado. Folha de S.Paulo, São Paulo, 31 ago. 1981.

CICLISTAS perdem a pista exclusiva no Ibirapuera. O Estado de S. Paulo, São Paulo, 23 abr. 1993.

É VIÁVEL o novo Parque Ibirapuera de Burle Marx?. Última Hora, Rio de Janeiro, 23 abr. 1974.

EM 30 DIAS, Burle Marx diz o que a cidade precisa fazer. O Estado de S. Paulo, São Paulo, 3 out. 1973. 
FERREIRA, Barros. Ibirapuera: a mais onerosa desolação de todo o Brasil. Correio Paulistano, São Paulo, 1959.

GASTOS com as obras do Ibirapuera. O Estado de S. Paulo, São Paulo, 21 ago. 1954.

IBIRAPUERA cai aos pedaços. Última Hora, Rio de Janeiro, 1959.

IBIRAPUERA só área de lazer. Diário de S.Paulo, São Paulo, 17 abr. 1974.

IBIRAPUERA terá sua nova reforma só a longo prazo. O Estado de S. Paulo, São Paulo, 22 ago. 1975 .

IBIRAPUERA vai ser restaurado. O Estado de S. Paulo, São Paulo, 30 jun. 1965.

LOTUFO, Zenon. Carta de encaminhamento de ante projeto de ajardinamento de Burle Marx para o Parque Ibirapuera. São Paulo, 27 de março de1953. Arquivo Histórico de São Paulo. Fls. n² Processo 1946-53.

MARKUN, Paulo. Um homem ainda às voltas com o futuro. Folba de S.Paulo, São Paulo, 15 dez. 1977.

MOORE, Rowan. The 10 Best Parks. The Guardian, London, 7 Aug. 2015.

MOREIRA, Adriana. Obra conta a história do Parque Ibirapuera. O Estado de S. Paulo, São Paulo, 24 jan. 1997.

NIEMEYER apresenta projeto de ampliação do prédio da Bienal. O Estado de S. Paulo, São Paulo, 10 jul. 1993.

NIEMEYER faz 70 anos, triste com São Paulo. Folha de S.Paulo, São Paulo, 15 dez. 1977.

NIEMEYER retorna para recuperar o Parque Ibirapuera. O Estado de S. Paulo, São Paulo, 31 jan. 1975.

NIEMEYER, Oscar. Mutilado o conjunto do Parque Ibirapuera. Módulo, Rio de Janeiro: [s.n.], 1955, p. 21. Edição especial.

O IBIRAPUERA volta ao passado e isso é ótimo. Jornal da Tarde, São Paulo, 26 mar. 1971. 
O IBIRAPUERA, ainda um parque inacabado. O Estado de S. Paulo, São Paulo, 22 jan. 1975.

O PARQUE que virou símbolo de São Paulo. Veja São Paulo, São Paulo, 12 ago. 1987.

O TRISTE exemplo do Ibirapuera. Folha da Tarde, São Paulo, 1959.

O VERDE em obras. Veja São Paulo, São Paulo, 23 set. 1992.

OLHE esse parque onde tudo mudará. Jornal da Tarde, São Paulo, 9 jun. 1969.

PATRIMÔNIO que se desfaz: Ibirapuera em estado deplorável. A Gazeta, São Paulo, 1959.

PEDRA em cima de pedra. Veja. São Paulo, 22 jan. 1992.

PREFEITA aprova o tombamento do parque Ibirapuera. Folba de S.Paulo, São Paulo, 12 jan. 1991

PREFEITURA pode abandonar projeto do novo Ibirapuera. O Estado de S. Paulo, São Paulo, 9 jul. 1974 .

PROCESSO 6.448/1955. Arquivo Histórico de São Paulo.

RECUPERAÇÃO do Parque Ibirapuera. A Gazeta, São Paulo, 25 abr. 1961.

REFORMA total no Ibirapuera. O Estado de S. Paulo, São Paulo, 19 nov. 1971.

RELATÓRIO sobre o lago do Parque Ibirapuera: comparação de estimativas.[1952]. Arquivo Histórico de São Paulo, processo n. 1.120, de 1952.

RUBERTI, Irene. IAB retoma projeto de teatro no Ibirapuera. O Estado de S. Paulo, São Paulo, 5 dez. 1992.

SÃO PAULO. Lei n. 10.929, de 11 de janeiro de 1991. Dispõe sobre a proteção e a ocupação do Parque do Ibirapuera. São Paulo: Diário Oficial do Município de São Paulo, São Paulo, ano 36, n. 8, p. 1, 12 jan. 1991.

SECRETARIA DE CULTURA DO ESTADO DE SÃO PAULO. Resolução n. 1, de 25 jan. 1992. Tombamento do Parque Ibirapuera. Diário Oficial do Estado de São Paulo, São Paulo, v. 102, n. 18, Seção I, p. 22. 
TEIXEIRA MENDES, Otavio Augusto. Parecer sobre projeto paisagístico. São Paulo, 1953. Arquivo Histórico de São Paulo, caixa 197, folha $n^{\circ}$, processo n ${ }^{\circ} 1936$, de 1953.

VILADARGA, Vicente. O verde vence o concreto no Ibirapuera. Jornal da Tarde, São Paulo, 5 jun. 1991.

VINCENT, Claude. Jardins do Parque Ibirapuera - Roberto Burle Marx. Brasil Arquitetura Contemporânea, São Paulo, no 2-3, Janeiro 1954. p.55-58.

LIVROS, ARTIGOS E TESES

ABREU, Ivanir Reis Neves. Convênio escolar: utopia construída. Dissertação (Mestrado em Arquitetura e Urbanismo) - Faculdade de Arquitetura e Urbanismo, Universidade de São Paulo, São Paulo, 2007.

ANDRADE, Manuella Marianna. O Parque do Ibirapuera: 1890 a 1954. Arquitextos, São Paulo, ano 05, n.051.01, Vitruvius, set. 2004. ago. 2004. Disponível em: <http://www.vitruvius.com. br/revistas/read/arquitextos/05.051/553>. Acesso em: 20 abr. 2017.

BARONE, Ana Cláudia Castilho. A oposição aos pavilhões do parque Ibirapuera (1950-1954). Anais do Museu Paulista: História e Cultura Material, São Paulo, vol. 17, n 2, pp. 295-316, jul.-dez. 2009.

Ibirapuera: parque metropolitano (1926-1954). Tese (Doutorado em Arquitetura e Urbanismo) - Faculdade de Arquitetura e Urbanismo, Universidade de São Paulo, São Paulo, 2007.

BURLE MARX, Roberto. O Projeto do Jardim das Esculturas. In: MODERNO MAM extra. Roberto Burle Marx, 100 anos: a permanência do instável. São Paulo: Museu de Arte Moderna de São Paulo, 2009. Livreto de exposição, jul.-set. 2009, Museu de Arte Moderna de São Paulo.

CAVALCANTI, Lauro; EL-DAHDAH, Farès; RAMBERT, Francis. Roberto Burle Marx, La modernité du paysage. Basileia: Birkhäuser, 2011.

CONSELHO DE DEFESA DO PATRIMÔNIO HISTÓRICO, ARQUEOLÓGICO, ARTÍSTICO E TURÍSTICO DO ESTADO DE SÃO PAULO. Processo de tombamento n. 25.767/87. São Paulo, 21 fev. 1992. Inscrição no Livro de Tombo n. 24, p. 307. 
D'ARAUJO, Maria Celina. O AI-5. Fatos e Imagens, Rio de Janeiro: CPDOC/FGV, [s.d.]. Disponível em: <http://cpdoc.fgv.br/producao/dossies/FatosImagens/AI5>. Acesso em: 2 jun. 2017.

GONÇALVES, Simone Neiva Loures. Museus projetados por Oscar Niemeyer de 1951 a 2006: o programa como coadjuvante. Tese (Doutorado em Arquitetura e Urbanismo) - Faculdade de Arquitetura e Urbanismo, Universidade de São Paulo, São Paulo, 2010.

KLIASS, Rosa Grena. Parques urbanos de São Paulo. São Paulo: Pini Editora, 1993.

LANDSCAPE Architecture in Brazil - Roberto Burle Marx. Washington D.C.: Smithsonian Institute, 1954. Livreto de exposição, maio-jun. 1954, Pan-American Union. Arquivo Histórico Wanda Svevo/Fundação Bienal de São Paulo.

LÉVI-STRAUSS, Claude. Tristes trópicos. São Paulo: Anhembi, 1957.

LOFEGO, Silvio Luiz. IV Centenário da Cidade de São Paulo: uma cidade entre o passado e o futuro. São Paulo: Annablume, 2004.

LEENHARDT, Jacques (Org). Nos jardins de Burle Marx. São Paulo: Perspectiva, 1994.

MACEDO, Silvio Soares. O paisagismo moderno brasileiro, além de Burle Marx. Paisagens em debate, São Paulo, n. 1, out. 2003. Disponível em: <https://www.scribd.com/document/99822093/ Paisagismo-Moderno\#download\&from_embed>. Acesso em: 2 jun. 2017.

MARIANO, Cássia. Preservação e paisagismo em São Paulo: Otávio Augusto Teixeira Mendes. São Paulo: Annablume; Fapesp; Fundação Maria Luísa e Oscar Americano, 2005.

MARINS, Paulo César Garcez. O Parque Ibirapuera e a construção da identidade paulista. Anais do Museu Paulista - História e Cultura Material, São Paulo, v. 6-7, p. 9-36, 1998-1999.

MODERNO MAM extra. Roberto Burle Marx, 100 anos: a permanência do instável. São Paulo: Museu de Arte Moderna de São Paulo, 2009. Livreto de exposição, jul.-set. 2009, Museu de Arte Moderna de São Paulo.

OLIVEIRA, Fabiano Lemes. Os projetos para o Parque Ibirapuera: de Manequinbo Lopes a Niemeyer (1926-1954). Dissertação (Mestrado) - Escola de Engenharia de São Carlos, Universidade de São Paulo, São Carlos, 2003a.

. O Parque do Ibirapuera: Projetos, Modernidades e Modernismos. In: SEMINÁRIO DOCOMOMO BRASIL, 5, 2003, São Carlos. Anais do $5^{\circ}$ Seminário Docomomo Brasil. São Carlos: [s.n.], 2003b. 
Modelos urbanísticos modernos e parques urbanos: as relações entre urbanismo e paisagismo em São Paulo na primeira metade do século XX. Tese (Doutorado) - Universitat Politècnica de Catalunya, Barcelona, 2008.

Para o Bem de São Paulo, Para o Belo em São Paulo: uma Proposta de Christiano Stockler das Neves para o Parque do Ibirapuera. In: ANAIS do VII Seminário de História da Cidade e do Urbanismo. Salvador: UFBA, 2002.

PREFEITURA DE SÃO PAUlO. Parque do Ibirapuera. Disponível em: <http://www. prefeitura.sp.gov.br/portal/a_cidade/historia/fatos_historicos/index.php?p=5604>. Acesso em: 2 jun. 2017.

SANTOS, César Floriano dos. Campo de Producción Paisajística de Roberto Burle Marx - "El Jardín Como Arte Público". Tese (Doutorado) - Escuela Técnica Superior de Arquitectura, Madri, 1999.

Artigo apresentado em 19/12/2016. Aprovado em 12/05/2017.

All the contents of this journal, except where otherwise noted, is licensed under a Creative Commons Atribution License

\section{(cc) BY}

